\title{
CONSTITUTION-MAKING: THE ROUND TABLE MODEL, POPULAR PARTICIPATION \& CONSTITUENT ASSEMBLIES
}

LAWS 526: Comparative Constitutionalism

Submitted for the LLB (Honours) Degree

Faculty of Law

Victoria University of Wellington

2014 
CONSTITUTION-MAKING: THE ROUND TABLE MODEL, POPULAR PARTICIPATION \& CONSTITUENT ASSEMBLIES

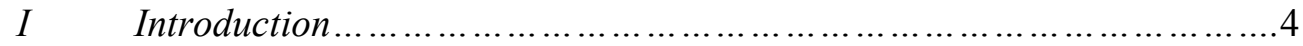

II Constituent Power: Popular Participation and Constituent Assemblies....7

III Analysis of the Literature ................................................. 13

IV The Round Table.......................................................... 16

V The Case Studies...................................................... 19

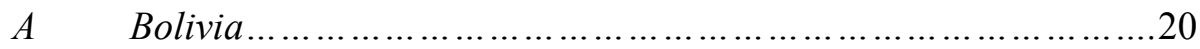

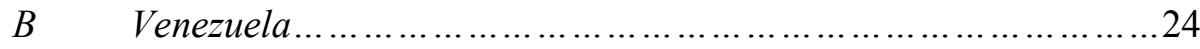

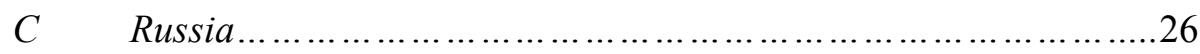

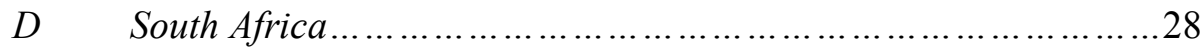

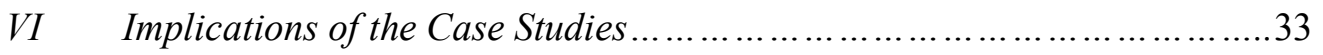

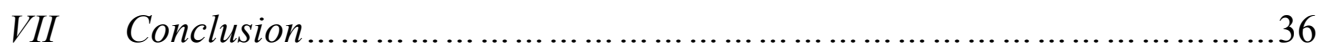

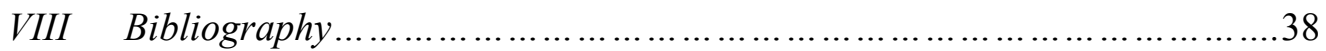




\section{Abstract}

In this paper, I will argue that the round table model is the ideal constitution making process. This is primarily because it gives clarity to the respective powers of the institutions involved in the process, and may prevent a dominant group or individual from unilaterally imposing a constitution. In building my argument, I outline the theory of constituent power and its corollaries of unlimited constitution making power and popular participation. I endeavour to portray the shortcomings of the theory itself, and, the dangers of its practical manifestation. Following this, I introduce the round table model as a preferable alternative, both theoretically and practically. To buttress my argument, I examine the Bolivian, Venezuelan, Russian and South African constitution making episodes.

\section{Keywords}

Constitution making

Round table model

Constituent power

Constituent assembly

Popular participation

The text of this paper, excluding the abstract, non-substantive footnotes, and bibliography comprises approximately 14,729 words. 


\section{Introduction}

In this paper I will argue that the round table model, or "post sovereign constitutionmaking", 1 as Andrew Arato calls it, is the ideal constitution making process. The model can be summarised briefly as follows. There is a two stage process where two constitutions are made. The first constitution is an 'interim constitution,' that binds the makers of the second constitution, which is the 'final constitution'. The interim constitution can include both substantive limits and procedural rules, and is negotiated by a pluralistic group representing different interests in society. For example, in South Africa, this group consisted of the then current government and the opposition parties. A constitutional court will be established (if one does not already exist), which will police the final constitution maker to ensure compliance with the limits and rules laid down in the interim constitution. The body which negotiates the interim constitution is unelected, but a democratically elected assembly drafts the second and final constitution. ${ }^{2}$

I accord pre-eminence to the round table model primarily because an interim constitution negotiated by a broadly representative body gives clarity to the respective powers of the actors and institutions involved in the process, and may prevent a dominant group or individual from unilaterally imposing a constitution. The importance of an interim constitution is borne out by the lack thereof in the Venezuelan, Russian, and Bolivian processes, discussed in Part V. In the Venezuelan and Russian episodes, a lack of preconceived rules meant that dominant individuals were able to create the rules 'as they went,' in order to secure their control over the process, and to implement their agendas unimpeded. In the Bolivian example, a lack of ground rules led to a chaotic process, where the powers of the respective actors were not clear at the outset.

In my view, the round table model may resolve these problems. It can do this in two ways. Firstly, the constitution making body is limited by the interim constitution because there is a constitutional court to certify that the final constitution conforms to the interim constitution. The placing of limits on the constitution making body may prevent dominant individuals from creating a self-serving constitution. Secondly, a representative body negotiating an interim constitution may prevent the implementation of rules for the process that favour one group, and will take away the opportunity for a dominant individual, or group, to unilaterally create rules to their advantage. For example, in the Venezuelan case, a representative body may not have agreed to a non-proportional voting system for the election of the Assembly as this would mean that they were handing full power to Hugo Chávez. Neither would they have been likely to agree to the dissolution of Congress and the assumption of legislative powers by the Assembly, because this further served to concentrate

\footnotetext{
${ }^{1}$ Andrew Arato, "Redeeming the Still Redeemable: Post Sovereign Constitution Making" (2009) 22 Int J Polit Cult Soc 427, at 429.

2 Andrew Arato, "Conventions, Constituent Assemblies, and Round Tables: Models, Principles and Elements of Democratic Constitution-Making” (2012) 1 Global Constitutionalism 173; Andrew Arato, above n 1, at 430432.
} 
power with Chávez and his coalition partners. If a proportional system was used for the election of the Assembly, then it would have been very difficult for Chávez to unilaterally impose a constitution. While in the Russian example, a round table may not have agreed to the President appointing, rather than electing, the Constituent Assembly, and might have preferred an election using a proportional system. Admittedly, the above-explained argument is premised on the assumption that a round table body will want the constitution making body to be broadly representative and not be dominated by one group or individual, and, to this end, that they would prefer a proportional voting system over a non-proportional one.

I use the Bolivian example to claim that, amongst other things, constitution making in the midst of a 'constitutional moment' where there is increased support for constitutional change from the people is undesirable. This is especially so if there is violence or the potential for violence. Instead, a groundswell of support should trigger the round table phase, because if violence is inevitable, then it may be less disruptive to the actual constitution making if it occurs during the interim constitution making phase, rather than during the drafting of the final constitution. If there is a passionate and polarized public who mobilise on mass this may have an inhibitory effect on the assembly, as they might feel they are limited in their options because they do not want to inflame the public. This could mean that they may feel pressured to either reject a proposal that may cause a violent reaction, or support a popular proposal for fear of a violent reaction if it is not implemented.

I refer to the Venezuelan and Russian examples to claim that there is another danger in making a constitution while there is a constitutional moment occurring. A popular and charismatic leader may be able to more easily appeal to the constituent power theory and assert complete control over the constitution making process. I argue that this is another reason to implement the round table model, to prevent one party, or individual, from taking complete control on the back of popular momentum for constitutional change, because a representative body negotiating an interim constitution would be unlikely to agree to rules that allow one group to control the process.

While the round table model lacks some democratic legitimacy in that the interim constitution is negotiated by an unelected body, it still has legitimacy in the sense that the actors involved accept it as a legitimate method of constitution making. ${ }^{3}$

In arguing for a round table phase as the most important element in the constitution making process, I place less importance on popular participation, because I do not see 'the people' as having as much influence on the constitutional text as the formalised body of elites who actually write the constitution. For example, even in the South African process, which is heralded as a paradigmatic example of popular participation, ${ }^{4}$ it is not clear how much influence public submissions had on the text of the constitution that emerged out of the process. ${ }^{5}$ The round table phase will have more of an influence on the composition of the

\footnotetext{
${ }^{3}$ Andrew Arato, above n 1, at 434.

4 Dann, Philipp et al, Lessons Learned from Constitution-Making: Processes with Broad Based Public Participation (Democracy Reporting International, Briefing Paper No.20, November 2011), at 6.

5 Joel I. Colón-Ríos, "Notes on Democracy and Constitution-Making” (2013) 3 VUWLRP 21, at 31. 
body of elites who write the constitution and on the rules that they work within, and hence will have more influence on the constitution. However, despite the lesser influence popular of participation, it is still an important ingredient in the constitution making process and I do not advocate a process devoid of popular participation. In my view, a blue print for a programme of organised popular participation has been set by the South African process, which I will discuss in Part V.

In Part II I will outline some of the academic arguments in favour of popular participation. Joel Colón-Ríos advocates popular participation in all phases of the constitution making process, whereas within the round table model there is no popular participation in the interim constitution making phase. Also, a central plank of his argument is that the constitution maker should be unlimited in its constitution making power, whereas under the round table model the maker of the final constitution is limited by the interim constitution.

Because the round table model involves limiting the constitution maker, it is necessary to address the theory of constituent power, originally championed by Emanuel Sieyès, and then later by Carl Schmitt, who claimed that the institution of the constitution maker must be unlimited in its constitution making power. Here I also discuss the constituent assembly, which is the practical manifestation of the constituent power theory. Many academics view the constituent assembly, imbued with unlimited constitution making power, as the ideal formalised constitution making body. ${ }^{6}$ I will argue that a broadly representative constituent assembly which is elected using a proportional system is the most appropriate constitution making body, but that by virtue of implementing the round table model, it will not have unlimited power, as it will be constrained by the interim constitution.

Following this, I discuss the implications of the round table model for the theory of constituent power. Then I proceed to review some of the critiques of the constituent power theory, and the dangers of the practical expression of the theory through an unlimited constitution making body. In particular, I outline Lars Vinx's argument that the theory is incoherent. I will build on Vinx's argument to justify the limitations placed on the constitution maker under the round table model. I then briefly summarise David Landau's concerns about popular participation and constituent power, and in Part V, with reference to the case studies, I argue that these concerns may be allayed through the round table model. After critiquing constituent power, I present the round table model, as explained by Andrew Arato, and offer it as a form of constitution making that is preferable to an unlimited constituent assembly.

In Part V, I present the Bolivian, Venezuelan, Russian, and South African case studies in an effort to show the practical advantages of the round table model. This section concludes with my analysis of the case studies in relation to the round table model. I argue that the use of a round table phase where government and opposition parties negotiate an interim

\footnotetext{
6 Joel I. Colón-Ríos, above n 5, at 27; Jon Elster "Ways of Constitution-Making” In Axel Hadenus (ed) Democracy's Victory and Crisis (Cambridge University Press, Cambridge, 1997), at 137; Jon Elster, "Legislatures as Constituent Assemblies" In Richard Brauman and Tsvi Kahana (ed) The Least Examined Branch: The Role of Legislatures in the Constitutional State, (Cambridge University Press, Cambridge, 2006).
} 
constitution which lays out the rules for the constitution making process and the principles that it will be bound by should be present in every constitution making episode.

\section{Constituent Power: Popular Participation and Constituent Assemblies}

Until fairly recently, there was generally mistrust in the ability of 'the people' to grasp constitutional issues, and to understand the dynamics of state power. ${ }^{7}$ For this reason, direct participation of the people in constitution making (or ordinary law making) was not promoted, and representative democracy was the norm. ${ }^{8}$ That is, the people democratically elect representatives to govern on their behalf.

However, the tide of opinion has changed. It is now common and expected practise to include popular participation in the constitution making process. It is seen as an essential element in the democratic legitimacy of the constitution. ${ }^{9}$ Furthermore, popular participation is emerging as (or already is according to some) an international norm. ${ }^{10}$ However, the preponderance of popular participation is not simply due to pragmatic evolution, it is ideologically driven by the constituent power theory.

Since the late 1980s there has been an increasing academic interest in the relationship between democracy and constitutionalism. There has been a lot of attention focussed on how to increase the 'democratic legitimacy' of the process of constitution-making. ${ }^{11}$ Under this process based approach, the legitimacy of a constitution is determined by its authorship, and in this respect popular participation ensures that the "revolutionary will of the people" is connected to the making of the constitution. ${ }^{12}$

Although this theory has been solidified and clearly articulated in more recent times, it has classical roots. John Locke, writing in the seventeenth century, stated that the "constituted commonwealth" is subordinate to the "supream power" possessed by the original constituting community to alter or overthrow the existing form of government. ${ }^{13}$ During the Philadelphia Convention, when justifying the decision to meet without the authorisation of the constituted bodies, James Madison referred to the "transcendent and precious right of the people to abolish or alter their government as to them might seem most likely to secure their safety and happiness."14

\footnotetext{
${ }^{7}$ Yash Ghai, The Role of Constituent Assemblies in Constitution-Making (IDEA, 2006), at 4.

8 Andreas Kalyvas, "Popular Sovereignty, Democracy, and the Constituent Power" (2005) 12 Constellations 223, at 226.

${ }^{9}$ Zackary Elkins et al, "The Citizen as Founder: Public Participation in Constitutional Approval” (2011) 81 TLR 101 , at 101.

${ }^{10}$ Thomas Franck and Arun Thiruvengadam, "Norms of International Law Relating to the Constitution-Making Process", in Framing the State in Times of Transition: Case Studies in Constitution-Making (Laurel E Miller, 2010), at 14; Michelle Brandt et al, Constitution-Making and Reform: Options for the Process (Interpeace, 2011), at 81; Vivien Hart, Democratic Constitution-Making (U.S Int. of Peace, 12 2003), at 1.

${ }^{11}$ William Partlett, “The Dangers of Popular Constitution-Making” (2012) 381 Brook. J. Int'L L 194, at 194.

${ }^{12}$ At 197.

${ }^{13}$ John Locke, The Second Treatise of Government: An Essay Concerning the True Original, Extent, and End of Civil Government, ed. Peter Laslett (Cambridge, Cambridge University Press, 1991), at 366-367.

${ }^{14}$ James Madison, "The Federalist No. 40," The Federalist Papers, ed. Clinton Rossiter (New York, Modern Library, 1938), at 257-258.
} 
The modern manifestation of these ideas is the author based approach, which ties the legitimacy of the constitution to its authorship. Under this conception, the people are viewed as the appropriate authors of the constitution. This idea is expressed through Emmanuel Joseph Sieyès' "constituent power" theory. According to Sieyès, the 'nation' (the people) acted in two ways within a democracy. One way is acting indirectly through elected representatives in the legislature in their ordinary law making capacity. The other way occurs in exceptional circumstances, where the people exercise their "constituent power," to disestablish the existing order and replace it with a newly constituted government. Under this theory, a truly democratic constitution is one that is produced in an episode of mass popular participation when the people themselves can claim authorship of the constitution. ${ }^{15}$ For it to be said that 'the people' as a whole have acted, they must have acted outside the pre-existing constitution established under the old regime. For a constitution to have the status of higher law its foundation must be able to be separated from ordinary law and politics. ${ }^{16}$

Carl Schmitt echoes the ideas of Sieyès, and directly refers to Sieyès as the founder of the theory that the people are the subject of the constitution making power. Schmitt states that "the constitution making power is unified and indivisible... it is the comprehensive founder of all other 'powers' and 'separation of powers." ${ }^{\text {"17 }}$ He then states that there can be no restraints whatsoever on the "constitution making power."18

There have been others too, who have expressed similar beliefs. For example, James Wilson, at the Philadelphia Convention in 1787, stated that, "As our constitutions are superior to our legislatures, so the people are superior to our constitutions. The consequence is, that people may change constitutions whenever and however they please." ${ }^{\prime 19}$ As with Schmitt, Wilson expressed the view that the people are sovereign, and there can be no limits on their constitution making power, which is the crux of the theory. Maurice Duverger offers a contribution along similar lines, stating that, "It is the constitution that derives its authority form the constituent power, not the constituent power that derives its authority from the constitution." 20

Clearly, there is a lot of historical support for the idea that the people hold the extralegal and unrestrained power to make a constitution when they are characterised as the "original constituting power." ${ }^{21}$ There is also contemporary support for this theory too, ${ }^{22}$ which I will discuss below.

${ }^{15}$ Emanuel Joseph Sieyès, What is the Third Estate? S.E Finer ed. M Blondel trans. (London, Pall Mall Press, 1963), at 121-122.

${ }^{16}$ Thomas Paine, Rights of Man: Being an Answer to Mr Burke's Attack on the French Revolution, in Rights of Man, Common Sense and other Political Writings (J.S Jordan, 1791), at 122.

${ }^{17}$ Carl Schmitt, Constitutional Theory (Duke University Press, Durham and London, 2008), at 126.

18 At 130 .

${ }^{19}$ McClellan, James and Bradford, M.E eds. Jonathon Elliot's Debates in the Several State Conventions on the Adoption of the Federal Constitution as Recommended by the General Convention at Philadelphia in 1787,. (Cumberland VA: J. River, 1989), at 432.

${ }^{20}$ Maurice Duverger, "Legitimite des Gouvernements de fait" (1948) Revue du Droit Publique, at 78.

${ }^{21}$ John Locke, above n 13, at 366-367

${ }^{22}$ Joel I. Colón-Ríos, above n 5. 
Nowadays, there are two practical implications of the constituent power theory in the context of constitution making. Firstly, a constitution making episode must involve high levels of popular participation, to ensure that the constitution has democratic legitimacy, and that the people can claim authorship of it. Secondly, the people's constituent power should be formally embodied in a constituent assembly which is possessed of unlimited constitution making power and is thus superior to, and unrestrained by, the constituted organs of government (the executive, legislature, and judiciary). ${ }^{23}$

Joel Colón-Ríos advocates a high level of popular participation in constitution making because it is necessary to make the process democratic. ${ }^{24}$ In the ideal constitution making episode the people would "come together, as political equals, and exercise their unlimited constitution making power". ${ }^{25}$ Colón-Ríos explains that the notions of the unlimited constitution making power and citizen involvement are expressed through the ideals of democratic openness, and popular participation, which he states are the basic components of democracy. ${ }^{26}$

Under his conception, a constitution making episode must give effect to the ideals of democratic openness and popular participation if it is to be considered democratic. ${ }^{27}$ With respect to popular participation this rules out "elite" or "expert" constitution making. ${ }^{28}$ There must be as much citizen involvement as possible through all stages of the process. The ideal of democratic openness requires that the constitution maker is subject to no external or legal limits whatsoever and is free to adopt any constitution it pleases. ${ }^{29}$

Colón-Ríos identifies three elements that would usually lead to a constitution making process that is consistent with the above-explained ideal of popular participation: the constituent assembly should be elected in such a way that promotes the participation of all sectors of society; popular participation should occur in all stages of the process; and constitution making should only occur in the context of strong popular support for constitutional change. ${ }^{30}$

Put simply, democratic openness requires that the constitution maker is subject to no external constraints in any way, shape, or form. There are three factors which must be satisfied in order for a constitution making episode to conform to the ideal of democratic openness: the constitution maker cannot be legally limited by any form of positive law; the constituent assembly must not be subject to any external limits; and the constitution making act should not result in the abolition of democracy. ${ }^{31}$

\footnotetext{
${ }^{23}$ Andreas Kalyvas, above n 8, at 229.

${ }^{24}$ Joel I. Colón-Ríos, above n 5, at 22.

${ }^{25}$ At 23.

${ }^{26}$ At 23 .

${ }^{27}$ At 23 .

28 At 28 .

${ }^{29}$ At 28 .

${ }^{30}$ At 31 .

${ }^{31}$ At 35. 
Colón-Ríos is not alone in his promotion of a constituent assembly endowed with unlimited constitution making power. There are many academics, and politicians, who advocate the use of an extraordinary constituent assembly (constituent assembly) - as opposed to an ordinary legislature - as the official body to draft a constitution. ${ }^{32}$ The promotion of the constituent assembly is linked to the theory of constituent power, and, more generally, is said to increase the democratic legitimacy of the constitution making process. ${ }^{33}$

A constituent assembly can be differentiated from an ordinary legislature because it is a body which is convened (usually elected) for the sole purpose of constitution making ${ }^{34}$ and it ceases to exist once the process is complete. It can be described as 'extraordinary' because it is not a normal and permanent government institution. ${ }^{35}$

Jon Elster does not claim that constituent assemblies (which he refers to as constitutional conventions) produce better constitutions than ordinary legislatures, but rather, he argues that in terms of procedure they "are more likely to embody the process of free and unconstrained deliberation amongst all parties." ${ }^{36}$ Further, when explaining his normative theory of constitution making Jon Elster states that, "The most important desideratum is probably that constitutions be written by specially convened assemblies and not by bodies that also serve as ordinary legislatures. ${ }^{, 37}$ One of the reasons for this is that the legislature has an inherent interest in its own power within the constitution, and, as such, should not be "allowed to be the judge of its own cause." 38

Elster claims that constituent assemblies are more likely than legislatures to allow for reason to prevail over interest, and passion. ${ }^{39}$ This also gives the constitution more legitimacy because it is not viewed as a simple case of bargaining between interest groups. ${ }^{40}$ According to Elster, with greater legitimacy, comes greater stability. ${ }^{41}$

He claims that legislatures that accord themselves the power to make a constitution may be criticised, because they were not elected for that task. ${ }^{42}$ Another manner in which he sees legislatures as inferior is that there are usually relatively unrepresentative, because they are most often elected using either a majority voting system, or a proportional voting system with a high threshold. ${ }^{43}$ Elster believes that a proportional voting system, with a low threshold, should be used to elect a constitution making body. ${ }^{44}$ A more representative body

\footnotetext{
${ }^{32}$ See Joel I. Colón-Ríos, above n 5; Jon Elster "Ways of Constitution-Making", above n 6; Jon Elster, "Legislatures as Constituent Assemblies", above n 6.

${ }^{33}$ See Joel I. Colón-Ríos, above n 5, at 27.

${ }^{34}$ At 27; Jon Elster, "Legislatures as Constituent Assemblies" above n 6, at 182.

${ }^{35}$ Joel I. Colón-Ríos, above n 5, at 27.

${ }^{36}$ Jon Elster, "Legislatures as Constituent Assemblies" above n 6, at 185.

37 Jon Elster "Ways of Constitution-Making" above n 6, at 137.

${ }^{38}$ At 138 .

${ }^{39}$ Jon Elster, "Legislatures as Constituent Assemblies" above n 6, at 185.

${ }^{40}$ At 185.

${ }^{41}$ At 186

${ }^{42}$ At 186

${ }^{43}$ At $186-187$.

${ }^{44}$ At 187.
} 
enjoys more legitimacy and thus so too will the constitution that emerges from this body. $\mathrm{He}$ therefore sees the choice of electoral system as a key element. ${ }^{45}$

Elster claims that "individual and groups interest are substantially less important in constitution making than in ordinary legislation." addressed in a constitution are, according to Elster, less susceptible to personal interest. The majority needed for a presidential veto or the frequency of general elections, are examples of the relative unimportance of some matters typically addressed in a constitution, in terms of self-interest to the framers. ${ }^{47}$

Another problem for Elster with a legislature is that debates will be public, whereas he claims that private discussions are preferable because there is more scope for rational discussion, rather than the "rhetorical overbidding" 48 which is likely in public debates.

When the legislature performs the dual role of legislation and constitution making, Elster sees a danger that politicians may put forward their proposals as constitutional, rather than legislative, in order to negate the possibility of having the measure vetoed. This risk was present in the Assemblee Constituante where legislative provisions were subject to a royal veto but constitutional provisions were not. ${ }^{49}$

As with Elster, Joel Colón-Ríos claims that the constituent assembly is an essential element in the constitution making process. But unlike Elster, Colón-Ríos does not add the qualification that it is "probably" the most important requirement in the process. Instead, he is more emphatic and claims that it is the most important element in terms of ensuring the democratic pedigree of the process. ${ }^{50}$ The assembly can be seen as a practical expression of the constituent power theory, because it is "commissioned exclusively for the exercise of constituent power, the unlimited constitution making power that is said to rest with the people in a democracy.",51

By choosing the constituent assembly as the proper constitution making body, the legislature and the executive are automatically rejected. He states that executive made constitutions are clearly inimical to popular participation, and apart from externally imposed constitutions, they involve the lowest level of popular participation. ${ }^{52}$ But, as he explains, there are in fact many reasons to see an ordinary legislature as an appropriate constitution making body. The members of the legislature are directly elected, they represent major societal interests, and they are directly accountable to their constituents in periodic elections. Even if there is limited participation in the drafting stage, a draft prepared by a legislature can still be subject to ratification in a referendum. The concern that a legislature lacks democratic pedigree because it was not elected to make a constitution could be ameliorated by calling a

\footnotetext{
${ }^{45}$ At 187.

${ }^{46}$ At 191.

${ }^{47}$ At 190 .

${ }^{48}$ At 191.

${ }^{49}$ At 191.

${ }^{50}$ Joel I. Colón-Ríos, above n 5, at 27.

${ }^{51}$ At 27.

${ }^{52}$ At 27.
} 
special election to grant them constitution making power. Both a legislature and a constituent assembly are comprised of representatives, neither body involves the citizenry coming together as one and deliberating. Although the constituent assembly replicates the legislature in that regard, it can be contrasted in that it can be characterised as a break from legal continuity within the existing order. Its claim to possess constituent power may have the effect of delegitimising the constituted powers like the courts and the legislature. ${ }^{53}$

However, despite all these factors, Colón-Ríos still prefers a constituent assembly over an ordinary legislature. He provides three reasons. The first is that the legislature's power is regulated by the constitution, so the constitution maker may wish to reform it. As such, along with Elster, Colón-Ríos believes that the legislature should not be the master of its own cause. This means that the legislature is an inappropriate body in terms of achieving the ideal of democratic openness which requires that the fundamental form of government can be questioned. Moreover, if the legislature drafts the constitution then it is difficult to differentiate the constitution making process - as one of higher law making - from ordinary day to day politics. In this regard, a constituent assembly is preferable because it signals to the public that this is a special process which stands apart from ordinary politics and, as such, may encourage people to participate more than they would if an ordinary legislature was making the constitution. In sum, a constituent assembly is the perfect vehicle for the exercise of unlimited constitution making power because "it stands above and outside the ordinary institutions of government, including the fundamental laws." ${ }^{.54}$

The second reason builds on the first. A legislature has the mandate to make day to day governance decisions. Because of this, it is dominated by traditional political parties and interest groups. In contrast, a constituent assembly is unconcerned with day to day decisions and instead is focussed solely on fundamental law. For this reason, it may prompt new people and groups who have traditionally been marginalised or disenchanted with politics to participate. These people and groups may jump at the chance to participate in the reconfiguration of the institutions which they have lost faith in. ${ }^{55}$

The last reason involves a factor that is also held against constituent assemblies - the fact that they are not accountable through re-election, whereas members of a legislature are. However, Colón-Ríos sees this is an advantage in terms of democratic openness because the members of an assembly do not have to worry about re-election so they will: ${ }^{56}$

...feel free to propose and support novel measures beneficial to society at large or to put into question long established institutions, even against the opposition of small but powerful sectors of society.

\footnotetext{
${ }^{53}$ At $27-28$.

${ }^{54}$ At 28 .

${ }^{55}$ At 28-29.

${ }^{56}$ At 29.
} 
But assuming that the referendum will be subject to ratification in a referendum then they still cannot ignore the views of the citizenry. ${ }^{57}$

In this section I have outlined the conceptions of constitution making which favour high levels of popular participation, and unlimited constitution making power within a constituent assembly. From Schmitt and Sieyès, through to Colón-Ríos, these conceptions are grounded on the theory of the constituent power.

\section{Analysis of the Literature}

I now turn to a discussion of the implications for the constituent power theory for the round table model, and to various critiques of the constituent power theory and its corollary of unlimited constitution making power. Following this, I will outline the round table model, and argue that this may be a preferable to unlimited constitution making power within a constituent assembly, on both a theoretical and practical level.

The implementation of the round table model is incompatible with Colón-Ríos' conception of democratic openness, and with the theory of constituent power as espoused by Sieyès et al, because it means that the constitution maker will be bound by the principles and rules contained in the interim constitution, rather than having unlimited constitution making power. However, in my view, a degree of democratic openness can be traded off for the practical benefits to be gained from the round table phase: the creation of certainty and the prevention of unilateral exercises of power by constraining the assembly with the interim constitution. The round table model is able to achieve this by applying constitutionalism to the process of constitution making. I mean this in the sense that the process of constitution making itself occurs within limits, just as a constitution binds the actors who are subject to it to act within preconceived limits.

The evidence shows that executive made constitutions do have a tendency to selfaggrandise the executive. ${ }^{58}$ However, the theory that the constituent assembly has an advantage in terms democratic openness is only applicable if the members of the assembly are not also members of the legislature, or affiliated with political parties in the legislature. In all the case studies contained in this paper, members of the assembly were also members of the legislature or were at least affiliated with major political parties. This fact also nullifies the perceived advantage of members of an assembly being better able to put the power of the legislature into question in the new constitution. In any event, there is evidence that parliamentary constitution makers do not typically self-aggrandise their power within a constitution. ${ }^{59}$ And, moreover, there is some evidence that constituent assemblies ascribe more power to the legislature than a legislature does. ${ }^{60}$ However, there are examples of

\footnotetext{
${ }^{57}$ At 29.

58 Tom Ginsburgh et al, "Does the Process of Constitution-Making Matter?" (2009) 47 Annu. Rev. Law Soc. Sci. 5.1, at 5.13.

${ }^{59}$ Zachary Elkins and Tom Ginsburgh, "Can We Trust Legislators to Write Constitutions?" (paper presented at the conference "The Gap Between Parchment and Practise: Ambivalent Effects of Constitutions in Developing Countries," American University, May 28-29, 2013), at 1.

${ }^{60}$ Tom Ginsburgh et al, above n 58, at 5.13.
} 
individuals within a constituent assembly, imbued with unlimited constitution making power, creating more power for their position within the constitution. In these cases, a constitution which is ostensibly made by a constituent assembly, is for all intents and purposes, in fact an executive made constitution. ${ }^{61}$

David Landau prefers constitution making by an ordinary legislature. He claims that there should be more emphasis placed on avoiding worst case outcomes rather than idealistically aspiring for best case outcomes. ${ }^{62}$ In particular, the process should seek to restrain the unilateral exercise of power by dominant groups or individuals. In this respect, constituent assemblies are inappropriate constitution making bodies because they may be harder to restrain by the courts and parliamentarians when they are operating under the ideology that the constituent assembly is an untouchable original constituent power. ${ }^{63} \mathrm{He}$ echoes the claims of William Partlett, who believes that when 'strongmen' cut from the ilk of Hugo Chávez or Boris Yeltsin are backed by this ideology, it may be easier for them to unilaterally control the process and create self-serving constitutions. ${ }^{64}$

Landau claims that the classical theorists like Sieyès and Schmitt are not really concerned with the practical implications of their theories. ${ }^{65}$ According to Landau, they simply explain that there must be a relationship between the constituted powers and the constituent power where the latter has power over the former. ${ }^{66}$ Landau does not so much critique the theory itself, but rather, the practical ramifications of the theory which is that the constitution making process should be highly participatory. ${ }^{67}$ In his view, popular participation has the potential to "greatly increase the risk of destabilising outcomes and worst case scenarios." ${ }^{.68}$ In particular, participation may tend to be me more of a hindrance than a help within a "poorly institutionalised environment." ${ }^{69} \mathrm{He}$ cites the Bolivian constitutionmaking episode of 2006-2009 as an example of constitution making with high levels of popular participation within a poorly institutionalised environment that hindered the ability to negotiate a constitution. ${ }^{70}$ Landau claims that in many instances the central focus of constitution making should be restraining unilateral exercises of power. ${ }^{71}$

As well as the practical dangers involved in the expression of the constituent power theory, the theory itself has not been immune from criticism. Lars Vinx is not convinced by the constituent power theory. He deconstructs Schmitt's constitutional theory, which Vinx claims is the driving force behind contemporary arguments in favour of popular

\footnotetext{
${ }^{61}$ For example Hugo Chávez in Venezuela, see David Landau, "Constitution-Making Gone Wrong” (2013) 645 ALR 923; Boris Yeltsin in Russia, and Aleksandr Lukashenko in Belarus, see William Partlett, above n 11.

${ }^{62}$ David Landau, above n 61, at 923.

${ }^{63}$ At 931.

${ }^{64}$ See David Landau, above n 61, at 926 in relation to Hugo Chávez; see William Partlett, above n 11, at 210226 in relation to Boris Yeltsin.

${ }^{65}$ David Landau, above n 61, at 934.

${ }^{66}$ At 934.

${ }^{67}$ At 935 .

${ }^{68}$ At 935 .

${ }^{69}$ At 935 .

${ }^{70}$ At 938 .

${ }^{71}$ At 923 . 
participation. ${ }^{72}$ Vinx states that a "strong conception of popular sovereignty...is incoherent and should not be used as the centrepiece of a democratic constitutional theory.",73

The particular aspect of the constituent power theory he attacks is the notion of the popular sovereign as a constituent power that exists prior to law. ${ }^{74}$ Before proceeding to his argument, Vinx gives a preliminary account of what he believes to be the theory of Schmitt et al as follows. A written constitution is only legitimate if it was made by the people as the constituent power and continues to enjoy their tacit support. The people as constituent power existed prior to, and independent of, any law, and are totally unrestricted in choosing their constitution. The people may exercise their constituent power anew at any stage. ${ }^{75}$

Vinx rejects this theory, because, according to him, it implies that there is no legitimate law. He states that: ${ }^{76}$

...the function of legitimate law is to reconcile us to the heteronomy that we inevitably suffer in a political community, where people who differ in their values, beliefs, and opinions must somehow take collective decisions that never fully satisfy all.

But, according to Vinx, advocates of strong popular sovereignty reject the idea of reconciliation of differences through legitimate law and believe that laws are only legitimate if they reflect an antecedent shared identity. However, Vinx claims that if we are in agreement about how our society should function because we share a "thick value laden identity"77 then we do not need any concept of legitimacy. And, if we do not share this identity, then strong popular sovereignty implies that there is no way that we can live legitimately under common laws. ${ }^{78}$ He claims that Schmitt's theory implies that: ${ }^{79}$

...a domestic constitution that is the product of a compromise amongst different groups - groups that each have their own political identity - and not the product of the exercise of strong popular sovereignty can be nothing more than a veiled form of subjection of one group to another.

Because Schmitt claims that the people possess a political identity prior to all legal or constitutional order he must explain what makes the pre legal political existence of the people. He claims that the political identity is based on a concrete quality of collective identity. This can include ethnic, religious, social, or economic identities. Whichever element forms the

\footnotetext{
${ }^{72}$ Lars Vinx, "The Incoherence of Strong Popular Sovereignty" (2013) 11 I CON 101, at 101. For modern adaptations of Schmitt's philosophy see Andreas Kalyvas, Democracy and the Politics of the Extraordinary: Max Weber, Carl Schmitt, and Hannah Arendt, (Cambridge University Press, Cambridge, 2009); Paul W. Kahn, Political Theology: Four New Chapters on the Concept of Sovereignty, (Colombia University Press, New York, 2012). Vinx also claims that the German Federal Constitutional Court used a notion of strong popular sovereignty similar to Schmitt's conception in a case regarding the constitutionality of the Treaty of Lisbon, see BVerfG, 2BvE 2/08, 30.6.2009.

${ }^{73}$ Lars Vinx, above n 72, at 101 .

${ }^{74}$ At 101 .

${ }^{75}$ At 102

${ }^{76}$ At 103

77 At 104

${ }^{78}$ At 103 .

${ }^{79}$ At 108 . 
primary identity for the people becomes their pre legal political identity. To be valid, the identity must give rise to a "friend-enemy" distinction. ${ }^{80}$ Thus Vinx claims that Schmitt reduces legitimacy to identity. That is, the constitution is only valid if it was made by the people (sharing a common identity), and it reflects their convictions. ${ }^{81}$ According to Schmitt, if a law does not reflect your convictions then it is not legitimate, ${ }^{82}$ or it must have been made by a group of people to whom you do not belong. ${ }^{83}$

Building on Vinx's analysis, I believe that Schmitt's conception is problematic on two counts. Firstly, it is unlikely that you will find a nation where every person agrees with every law, which means that the same law within the same nation could be legitimate to some but illegitimate to others. Secondly, there will be many nations where people do not share the same primary identity, so, again the same constitution will be legitimate to some but not to others, depending on their primary identity. Under Vinx's interpretation of Schmitt's theory, this would mean that if the law does not reflect the identity of the person, then they do not have to follow it, because it is not legitimate according to their identity, or that they are not really members of that political community, because they do not subscribe to that identity so they are in fact an 'enemy'.

If we accept that in a modern country the entire populace may not share the same primary identity, but regardless of that, they (or at least the majority of them) are willing to live together in a common political community, then a round table phase which involves representatives from the different interests and 'identities' in society determining the rules for the constitution making process is the best way to ensure that all 'identities' have a voice. The idea that you will find all the inhabitants of a country sharing the same identity - in the form of religion, or ethnicity for example - is inapplicable nowadays. To take New Zealand as an example, there will be citizens or permanent residents whose primary identity is as a 'kiwi,' but there will be others who may identify primarily along ethnic or religious lines and secondarily as 'kiwis'. This type of pluralism is a fact of many contemporary societies, and is recognised through the concept of dual citizenship.

\section{The Round Table Model}

Now that I have outlined some practical and theoretical issues with the constituent power theory, I will move to a discussion of Andrew Arato's views on the round table model. I would like to posit the round table model as a possible panacea for the ills of the constituent power theory.

Arato is a staunch advocate of the round table model. He refers to it as "post sovereign constitution making," because the "constituent power is not embodied in a single organ or

\footnotetext{
${ }^{80}$ At 110 .

${ }^{81}$ At 111 .

${ }^{82}$ The issue of legitimacy of law in Schmitt's theory has been identified by others, see David Dyzenhaus, Legality and Legitimacy: Carl Schmitt, Hans Keller and Hermann Heller in Weimar, (Oxford, 1999), at 38-101; Hasso Hofmann, Legitimacy Against Legality: The Development of Carl Schmitt's Political Philosophy, (Duncker and Humblot, Berlin, 2002).

${ }^{83}$ Lars Vinx, above n 72, at 112.
} 
instance." 94 The primary reason he advocates this model is that it provides a "democratic alternative to revolutionary constitution making that all too easily steps over the threshold to dictatorship." ${ }^{85}$ Arato explains that the model, which can be traced back to the American Revolution, was revisited in Spain in the 1970s, employed in Central Europe in the late 1980s, and was perfected in the South African episode, which is discussed later in this paper. ${ }^{86}$ The fundamental premise of the round table model is to apply constitutionalism to the process of constitution making. He claims that this is the preferable to the alternative option of "revolutionary-populist constitution making" which is what occurred in the Andean republics; Bolivia, Venezuela, and Ecuador. ${ }^{87}$

Arato states that the most important element is the making of an interim constitution that binds the makers of the second and 'final' constitution. ${ }^{88}$ There are two instances that contribute to the drafting; the group that negotiate the interim constitution, and the group that drafts the final constitution, which is always a freely elected body. The group which drafts the interim constitution is unelected and is usually comprised of major political groups (including the current government and opposition parties). Arato states that this body should include the "main political actors controlling or capable of controlling means of violence." 89 The drafting body of the final constitution should not be called a 'constituent assembly,' because it does not have unlimited constitution making power. ${ }^{90}$ It is the interim constitution that subjects the process of constitution making to constitutionalism, by constraining the makers of the final constitution. ${ }^{91}$

While the round table negotiating bodies technically have no legal status, as they are essentially private gatherings, the presence of the previous ruling party means that the provisions contained in the interim constitution are more than mere proposals which the ratifying body (usually parliament) can accept or reject. ${ }^{92}$ The limitations contained in the interim constitution, which the drafters of the final constitution will be subject to, can vary in their type and scope. They can be as minimal as providing for the ratification rules for the final constitution, but they can be much more detailed, and, amongst other things, can include rules regarding the make-up of the constitution making body, the voting rules they will be subject to, the role of external input, and the time frame for completion of the constitution. ${ }^{93}$

\footnotetext{
${ }^{84}$ Andrew Arato, above n 1, at 428.

${ }^{85}$ At 427 .

${ }^{86}$ At 428 .

${ }^{87}$ At 428. For information on the process in Ecuador see Maxwell Cameron and Kenneth Sharpe, "Andean Left Turns: Constituent Power and Constitution-Making" in Maxwell Cameron and Eric Hershberg (eds) Latin American Left Turns: Politics, Policies, and Trajectories of Change“(Lynne Rienner Publishers, Boulder, 2010); Renata Segura, Inclusion and the Politics of Constitution Making: Colombia and Ecuador (1991 \&1998), (New School University, 2007).

${ }_{88}$ Andrew Arato, above n 1, at 430.

${ }^{89}$ At 441.

${ }^{90}$ At $430-431$.

${ }^{91}$ At 431.

92 At 432 .

${ }^{93}$ At 432 . 
The round table model provides legal continuity, as there is no legal rupture between the old regime and the new, ${ }^{94}$ because the constitution makers usually revert to the amendment rule under the previous constitution when making the new constitution. ${ }^{95}$ However, Arato claims that the legality that is being relied upon may be 'fictional', as the amendment rule being used may not have been treated by the old regime as the actual rule of constitutional change. This is especially so when the previous regime was a dictatorship with a 'sham constitution," ${ }^{96}$ in the sense that government practise is incongruent with the written constitution. ${ }^{97}$ But this is not a major issue, because according to Arato, legal continuity with the old regime is not as important as legality of action when making the new constitution; that is, the following of the procedures for the round table model. ${ }^{98} \mathrm{He}$ cites the Iraqi constitution making episode of 2005 as an example of violation of procedural rules, which had negative consequences, and was widely criticised. ${ }^{99}$

This leads to a critical element that is necessary for the round table model to function properly; the ability for the interim constitution to be enforced. If the interim constitution cannot be enforced, then it cannot perform its vital function of regulating the drafting of the final constitution, and the rules of the process are liable to be violated. ${ }^{100}$ The enforcement occurs through the establishment of a constitutional court to certify that the final constitution produced by the constitutional assembly accords with the interim constitution. ${ }^{101}$ Parties can apply to the court for declarations that certain provisions of the draft constitution are unconstitutional, ${ }^{102}$ and if the application is successful, the court can then advise the assembly as to how to redraft the offending provisions. ${ }^{103}$

Arato explains that there is a prima facie issue of legitimacy with the round table model as the makers of the interim constitution are unelected, and they are binding the elected makers of the final constitution. ${ }^{104}$ But, Arato claims that the model can be legitimate in the sense that the "actual political actors, taking into account their identities and interests, come to regard a state of affairs, or a projected one, as valid."105

The limitations placed on the drafters of the final constitution are clearly in conflict with the theory of the people's unlimited constituent power. But, Arato questions the cogency of the constituent power theory. He refers to the argument made by Janos Kis that "the people

\footnotetext{
94 At 432 .

95 At 432 .

${ }^{96}$ For an in depth discussion of the concept of sham constitutions see David S. Law and Mila Versteeg, "Sham Constitutions," (2013) 1014 CLR 863.

${ }^{97}$ For example most constitutions contain prohibitions against torture, but many countries still practise torture, see David S. Law and Mila Versteeg, above n 96, at 868.

${ }_{98}$ Andrew Arato, above $\mathrm{n} 1$, at 433.

99 At 433. For more on the Iraqi constitution making process see Andrew Arato, "Post-Sovereign ConstitutionMaking and Its Pathology in Iraq" (2006-2007) 51 NYLSLR 535.

${ }^{100}$ At 433 .

${ }^{101}$ At 433 .

${ }^{102}$ See for example, Certification of the Constitution of the Republic of South Africa, CCT 23/96 [1996] ZACC 26.

${ }^{103}$ At 433.

${ }^{104}$ At 434.

${ }^{105}$ At 434.
} 
are never a primordial entity but are always legally constituted, and therefore with specific powers and limitations."106 Arato then refers to Maurice Hauriou's claim that constituent power is divisible; it can exist in both the people and the state simultaneously. The state is limited by popular consent, and the people are limited by state sovereignty. ${ }^{107}$

Arato describes the theory of unlimited constituent power of the people as an "unacceptable political mythology, based on incoherent originalism". ${ }^{108} \mathrm{He}$ claims that historical analysis and logic show that the legal identity of the sovereign people, which can only act through representatives, comes into existence through electoral rules and procedural rules that are 'given' to the people by elites. Without this constituting act of the elites, there would be no body referred to as 'the people' capable of political action. ${ }^{109}$ Under this conception, the limitations placed on the constituent assembly (as the representatives of the people) under the round table model are legitimate. He derides the "mythologizing"110 of the members of the constituent assembly as being identical to the people. The round table model does not equate the final constitution drafting body with the people, but, rather, accepts that they are representatives of the people, and as such are subject to limitations. ${ }^{111}$

Under my conception of constitution making, the presence of a constituent assembly is not the most essential element. As explained earlier, it is a round table phase. This belief is undergirded by both practical and theoretical concerns. The primary practical danger inherent in unlimited constitution making power is that it is susceptible of being abused when it is effectively concentrated in one group or individual, as is borne out by the case studies which follow hereafter. The theoretical concerns include the inability of the theory to allow the plurality of identities which is present in many contemporary nations to live legitimately under the same constitution, and on the questionable validity of the theory that the people are a primordial entity whose legal identity exists prior to the establishment of electoral and procedural rules by elites.

\section{Case Studies}

In this Part I outline the constitution making episodes in Bolivia, Venezuela, Russia, and South Africa. I will endeavour to portray the practical advantages of the round table model by reference to the South African process, and, conversely, to show the practical disadvantages of the processes involved in the other case studies. In particular, I claim that the self-ascribed unlimited constituent power of the constituent assemblies in the Venezuelan, and Russian cases led to the process being hijacked by dominant individuals who were able to unilaterally impose constitutions under the guise of 'constituent power'. While in Bolivia, a messy scenario unfolded, because the rules of the constitution making process were not preconceived. In my view, these eventualities may have been avoided by the utilisation of the

\footnotetext{
${ }^{106}$ Janos Kis, "Popular Sovereignty: The Classical Doctrine and its Criticism" 20061 Rev. Pol. Sci. 5.

${ }^{107}$ Maurice Hauriou, Precis de Droit Constitutionnel, $2^{\text {nd }}$ ed. (Paris, Sirey, 1929).

${ }^{108}$ Andrew Arato, above n 1, at 437.

${ }^{109}$ At 437-438. See also Hans Kelsen, On the Nature and Value of Democracy, (Tubigen J.C.B Mohr, 1929), at 14-18.

110 At 439 .

${ }^{111}$ At $439-440$.
} 
round table model. I also claim that the drafting of the final constitution should not occur in the midst of a 'constitutional moment' where there is a highly mobilised and polarised public, because this may inhibit the work of the drafters. Another danger is that it may be easier for a charismatic leader to take advantage of popular support for constitutional change, and control the process for their benefit. I suggest that the round table model may negate these potential occurrences.

\section{A Bolivia (2006-2009)}

The constitution making process in Bolivia began after a pacted political system based on consensus had broken down. From the early 1980s power was held in Bolivia by coalitions pursuing a broad neo liberal agenda that held their alliances together through a system of patronage. ${ }^{112}$ By the mid-2000s these parties were no longer seen as legitimate due to widespread corruption. It was thus a perfect storm for Evo Morales, who rose to power as the head of Movimiento al Socialismo (MAS) which promised to take Bolivia in a new direction, away from neo liberal policies, and to enfranchise the indigenous majority who had traditionally been marginalised. ${ }^{113}$ The MAS was not only a political party, but also the formalised manifestation of the social revolution that was fermenting at the time. In 2002 Morales was kicked out of Congress for leading protests against the Government. These protests were part of a broader societal dissatisfaction with the Government and their neoliberal policies which had resulted in numerous protests from 1999 onwards, and culminated in the protests in February and October 2003, which led to 30 and 59 casualties respectively. Many Bolivians felt disenfranchised by Government policies, and were suffering under economic hardship and poor living conditions. Thus, there was a groundswell of support for constitutional change. ${ }^{114}$ This is an important aspect of the Bolivian case, as this was constitution making in the midst of a social revolution, as opposed to the South African episode, where the drafting of the final constitution occurred just after a period of immense instability and violence.

Morales' party faced a vehement and well organised opposition. In general the opposition movement consisted of a greater proportion of non-indigenous and wealthy Bolivians situated in and around Santa Cruz, whereas Morales' movement included more indigenous and less wealthy Bolivians. ${ }^{115}$

He promised to re-found Bolivia on a more socially inclusive basis, and, to this end, he promoted the election of a constituent assembly. This measure was broadly supported by

\footnotetext{
${ }^{112}$ Eduardo A. Gamarra, "Bolivia: Evo Morales and Democracy," in Constructing Democratic Governance in Latin America, Jorge I. Dominguez and Michael Shifter eds. (The John Hopkins University Press, Maryland, $2003)$ at $124,125-30$.

${ }_{113}$ David Landau, above n 61, at 949-950.

${ }^{114}$ Robert R. Barr, "Bolivia: Another Uncompleted Revolution," (2005) 47 Latin American Politics and Society 69 , at 69-70.

${ }^{115}$ Rene Antonio Mayorga, "Bolivia's Democracy at the Crossroads" in The Third Wave of Democratization in Latin America: Advances and Setbacks, Francis Hagopian and Scott P. Mainwaring eds (Cambridge University Press, Cambridge, 2005), at 149; Maxwell Cameron and Kenneth Sharpe, above n 87, at 74.
} 
Bolivian political parties, including the opposition, who saw it as a means to gain greater regional autonomy. ${ }^{116}$

The MAS secured a clear majority of seats in the Assembly, thus the opposition parties lacked negotiating power. The opposition attempted to compensate for this by placing external restraints on the Assembly through the courts and Congress. But it was not clear as to what the ground rules were for the process, and whether, and to what extent, the external institutions could restrain the Assembly. At this point it is appropriate to mention the South African process where the rules were laid out by agreement in the interim constitution, which meant that there was certainty about the roles of all the actors in the process. Along with the lack of clarity in Bolivia, there was the mass mobilisation of "deeply invested" "117 and passionate groups. This combination of factors was the perfect recipe for a chaotic constitution making process.

In 2004 the previous Congress had passed a constitutional amendment allowing for the convocation of a constituent assembly, so in 2006 when president Morales called the election for the Assembly he was acting within the rules of the existing constitution. The law to allow the election of a constituent assembly was passed in 2006 and it contained many restraints on the process. Firstly, the electoral rules were proportional, which meant that the MAS could not completely dominate the Assembly. Secondly, the Assembly was to be held in Sucre, a fairly neutral city which was not a stronghold of either Morales or the opposition's supporters. Thirdly, the constitutional text required a two thirds majority in the Assembly, before it was put to the vote in a national referendum, ${ }^{118}$ meaning that there would need to be some support from the opposition and Morales could not simply impose a constitution. According to Landau, the rules of the process were intended to avoid the unilateral imposition of a constitution by one side on the other. ${ }^{119}$

The electoral rules had their intended effect. The opposition won more than a third of the seats in the Assembly, so Morales had to compromise with them to a degree, because he relied on their support to pass the constitution. However, a major issue in the process was the instability and contestability of the external constraints on the Assembly. Prior to first the meeting of the Assembly, the MAS talked about the possibility of exercising "original constituent power." 120 Morales belief was that the Assembly must be above all the constituted powers, but only subservient to the people. ${ }^{121}$ However some external restraints held, for example, the Electoral Court suspended a vote gained by MAS to hold a referendum because the opposition had been prevented from entering the floor to vote. ${ }^{122}$ This issue may

\footnotetext{
${ }^{116}$ David Landau, above n 61, at 950.

117 At 951.

${ }^{118}$ At 952-953.

${ }^{119}$ At 953 .

${ }^{120}$ At 953.

${ }^{121}$ Asamblea originaria genera contradicción en el Gobierno, La Prensa, July 28, 2006, <constituyentesoberana.org/info/>; see also El MAS planteará poderes absolutos en la Asamblea, Agencia De Noticias Fides, Aug. 17, 2006, <constituyentesoberana.org/info/>.

${ }^{122}$ David Landau, above n 61, at 956; see also Fabrice Lehoucq, "Bolivia’s Constitutional Breakdown" (2008) 19 J. Democracy 110, at 118.
} 
not have arisen had the rules of the constitution making process been agreed upon beforehand, and that the Assembly would be limited by the interim constitution.

There was also a lack of clarity as to what the two thirds majority approval of the constitution meant. MAS argued that it was approval of the text as a whole, whereas the opposition claimed that it was for each individual article. This disagreement led to a six month stand-off within the Assembly, including a hunger strike by some of the female members. This was accompanied by mass demonstrations on both sides. ${ }^{123}$ Eventually the parties compromised and agreed to use the two thirds rule for all articles of the proposed constitution up until July 2007. ${ }^{124}$ Again, we see the value of the interim constitution, which laid down the ground rules in the South African process. The uncertainty and delay in Bolivia could have been avoided if the rule regarding approval of the text had been clearly enunciated in the first place.

A further issue arose when it was suggested that the capital should be moved to Sucre from La Paz. ${ }^{125}$ When the MAS passed a motion tabling the proposal, there was an outpouring of violence within Sucre, which prevented the Assembly from meeting for around four months. After negotiations failed between the Assembly members, the president of the Assembly convoked the Assembly in a military compound in Sucre in order to approve the text, but the opposition boycotted the Assembly. ${ }^{126}$ The Assembly was then moved to Oruro, a city near La Paz, and the text was approved while supporters of Morales encircled the building to prevent the opposition members of the Assembly from entering. ${ }^{127}$

But there was still a final hurdle for MAS to get through. The law convoking the Assembly required that Congress call the referendum for ratification of the text, and there were enough members of the opposition in the Congress to prevent the referendum. ${ }^{128}$ This was met with violence and mass protests by MAS supporters, who prevented the opposition members from being at Congress, so the referendum was able to be enacted by the MAS who now enjoyed a two thirds majority in the Congress with the absence of the opposition. ${ }^{129}$ In turn this was met with popular uprisings by opposition supporters around Santa Cruz and, as mentioned earlier, resulted in the Electoral court suspending the calling of the referendum and sent it back to Congress again. ${ }^{130}$ The Electoral Court proved to be the opposition's only real mechanism to restrain the MAS, because the Constitutional Court was inoperable, as five members had resigned after impeachment proceedings were bought against them by members of the MAS. ${ }^{131}$ Eventually the MAS ceased to resist the restraints placed on the Assembly and a constitution was negotiated with the opposition. They reached agreement in October 2008. The referendum was called by Congress, and the Constitution passed into law with a 61

123 At 954; see also, for example Presidente lamenta convocatoria a paro, El Diario, Dec. 1, 2006, $<$ constituyentesoberana.org/info/ $>$.

${ }^{124}$ David Landau, above n 61, at 954.

${ }^{125}$ At 955.

${ }^{126}$ At 956.

${ }^{127}$ At 956.

${ }^{128}$ At 956.

${ }^{129}$ Fabrice Lehoucq, above n 122, at 118.

${ }^{130}$ Resolucion No. 013/2008, Mar 7, 2008.

${ }^{131}$ Fabrice Lehoucq, above n 122, at 119-120. 
per-cent majority. ${ }^{132}$ The text included concessions to the opposition, like greater regional autonomy, and less state control of the economy. ${ }^{133}$

Landau believes there are several important points to take from the Bolivian example. The first is that the external restraints placed on the Assembly, which eventually held, managed to prevent the MAS from unilaterally imposing a constitution, and allowed the opposition to gain concessions in the final text. But although the external forces eventually proved effective, their role was highly contested and uncertain. At times the MAS toyed with the prospect of the Assembly exercising original constituent power, and thus, being above the constituted powers. This instability was exacerbated by very high levels of popular participation through mass mobilisation. Landau claims that the process highlights the dangers involved in constitution making within a poorly institutionalised context, where there is a passionate, hyper vigilant, and polarised citizenry. ${ }^{134}$

According to Landau, popular participation was problematic for the Assembly. ${ }^{135} \mathrm{But}$ Landau does not emphasise that this constitution making episode occurred during a social revolution. As such, it is perhaps unrealistic that it would be a completely peaceful process. However, it does highlight another advantage of a negotiation phase employed in the ro9unf table model. It may have been more helpful to negotiate an interim constitution first, and then when the final constitution was made, the conditions may have been more stable. But it is difficult to predict that this would be so, just because that is what happened in South Africa. Even if an interim constitution was made, there is no guarantee that the Assembly would be have been able to go about their work peacefully without mass demonstrations and violence. However, it is perhaps more desirable, if violence is inevitable, that the violence occurs in the interim constitution negotiation phase, rather than during the drafting of the final constitution in the Assembly. If violence occurs during the drafting stage it may limit the options available to the drafters, for fear of rousing the passions of their supporters with a proposal that was contrary to their wishes, or for not supporting a popular proposal. For example, most members of the opposition were not overly concerned with a proposal to move the capital city from La Paz to Sucre, but embraced the move once public protests over tabling the proposal became large. ${ }^{136}$

To Landau's views I would add the following comments. The Bolivians could have taken a leaf out of the South African constitution making book. In particular, the negotiation of an interim constitution, that set clear ground rules that all the political parties agreed upon, could have aided in terms of creating stability and certainty in the process. It would have been clear before the convocation of the Assembly what the respective powers of the Assembly and the pre-existing institutions were. Of course, as with South Africa, this would not have removed the possibility of violence, but at least it would have created the possibility that the process of negotiating the constitution in the Assembly may have been able to occur

\footnotetext{
132 David Landau, above n 61, at 957.

${ }^{133}$ At 957.

${ }^{134}$ At 935 .

${ }^{135}$ At 940 .

${ }^{136}$ At 955-956. 
under more peaceful conditions, and the potential for violence would not have loomed so large in the minds of the Assembly members when making decisions. On the other hand, a more pessimistic view is that the violence and obstructive mass mobilisation would have still occurred, because there was so much at stake, as the country was in the midst of a social revolution.

\section{B Venezuela (1999)}

The legitimacy of the two main political parties in Venezuela - who had monopolised political power under the Punto Fijo pact ${ }^{137}$ - had been damaged beyond repair by the early 1990s due to embedded corruption coupled with a failing economy. ${ }^{138}$ Hugo Chávez won power in 1998 and promised to change Venezuela's political system. ${ }^{139}$ He took advantage of the groundswell of support for constitutional change, ${ }^{140}$ and widespread popular dissatisfaction with the traditional elites, to neutralise the opposition forces, and assume total control over the constitution making process.

Unlike the South African process, there was no round table phase. Instead, Chávez was able to unilaterally determine the rules for the constitution making process. ${ }^{141}$ His first, and perhaps most important move, was to employ a majoritarian system to elect the Assembly. ${ }^{142}$ This system converted the 60 per-cent vote that his movement won into 95 percent of the seats in the Assembly, albeit in coalition with other parties. ${ }^{143}$ This meant that his coalition faced no opposition from within the Assembly. ${ }^{144}$ The opposition forces and traditional elites were thus effectively excluded from participating in the writing of the new constitution. $^{145}$

In the absence of intrinsic restraints due to diversity within the Assembly, external restraints appeared to be the only means through which Chávez's power could be bridled. ${ }^{146}$ However, the Venezuelan Supreme Court applied the constituent power theory and stated that the people's constituent power, as manifested in the Assembly, was "prior and superior to the established judicial regime." ${ }^{\prime 47}$ Thus, the Assembly was not limited by any positive law. The

\footnotetext{
${ }^{137}$ Maxwell Cameron and Kenneth Sharpe, above n 87, at 106.

138 David Landau, above n 61, at 940-941.

139 Steve Ellner, Rethinking Venezuelan Politics: Class, Conflict, and the Chávez Phenomenon, (Lynne Rienner Publishers, Boulder, 2008), at 95-99; Maxwell Cameron and Kenneth Sharpe, above n 87, at 105.

${ }^{140}$ Maxwell Cameron and Kenneth Sharpe, above n 87, at 106.

${ }^{141}$ David Landau, above n 61, at 941.

${ }^{142}$ Maxwell Cameron and Kenneth Sharpe, above n 87, at 105.

${ }^{143}$ Steve Ellner notes that there were "hard line" and "soft line" factions within Chávez's movement; see Ellner, above $\mathrm{n} 139$, at $139-173$.

144 David Landau, above n 61, at 941; for more on the Venezuelan constitution making episode see also Maxwell Cameron and Kenneth Sharpe, above n 87; Donna Lee Van Cott, “Andean Indigenous Movements and Constitutional Transformation: Venezuela in Comparative Perspective" (2003) 301 Latin American Perspectives 49.

${ }^{145}$ Maxwell Cameron and Kenneth Sharpe, above n 87, at 106.

${ }_{146}$ David Landau, above n 61, at 942.

147 Caso: Junta Directiva de la Fundacion para los Derecrios Humanos (Supreme Court of Justice, PoliticalAdministrative Chamber), Revista Del Derecho Publico, 77-80, 1999, at 56.
} 
Court subsequently changed tack, and stated that the Assembly was bound to the spirit of the existing constitution. ${ }^{148}$

There were further court rulings that attempted to circumscribe the powers of the Assembly within existing law, but when the Assembly was convoked Chávez immediately declared that it was "most sovereign." the existing governmental institutions, as they were populated by opposition forces. To add a veneer of legality to his procedures, he declared a state of national emergency, which gave the Assembly the mandate to reorganise state powers. ${ }^{150}$ The Supreme Court was warned that its members would be replaced if they attempted to meddle with the Assembly's work. Large numbers of the judiciary were replaced by judges appointed directly by the Assembly. ${ }^{151}$ The Congress, which had convened for an emergency sitting to discuss the appropriateness of the Assembly's actions, had its powers sharply circumscribed, and was later dissolved by the Assembly. The Constituent Assembly then assumed legislative powers, along with constitution making powers. ${ }^{152}$ In this way, the Venezuelan process went much further than the Bolivian process, because Morales did not dissolve Congress or ascribe legislative powers to the Assembly. ${ }^{153}$ Also, state legislatures were placed under the supervision of the Assembly. ${ }^{154}$

The drafting phase was relatively quick, taking only a few months. In Landau's view, this was because most of Chávez's energy was spent in supressing and dismantling state institutions. Although there was a reasonable amount of public participation - for example through submissions from civil society groups to the Assembly ${ }^{155}$ - Landau claims that it was merely "window dressing." "156 Although some of the content of the submissions were incorporated into the constitution, this was at the level of details, whereas the overall structure, and the most important points of the constitution, remained as Chávez had initially proposed them. ${ }^{157}$

Chávez's ability to unilaterally write electoral rules that gave him full and unbridled power in the Assembly highlights the dangers of the constituent power theory when it is effectively concentrated in one individual. The presence of a round table phase including representatives from most (ideally all) sectors of society, can negate this risk because it is

148 Caso: Gerado Blyde Perez, Clarification, (Supreme Court of Justice, Political Administrative Chamber) Revista Del Derecho Publico, 77-80, 1999, at 85, 88.

149 Hugo Chávez Frías, Documento Fundamtentales de la Republica Bolivariana de Venezuela, (Caracas, Venezuela, Ediciones de la Presidencia de la Republica, 2000).

${ }^{150}$ David Landau, above n 61, at 946.

${ }^{151}$ However, there was also a lack of independence under the previous regime too, where the political parties were very influential in choosing the appointment of judges. See Maxwell Cameron and Kenneth Sharpe, above n 87, at 106.

${ }^{152}$ At 100

153 At 100. However, Rafael Correa of Ecuador followed Chávez's lead by dissolving Congress and granting legislative powers to the Assembly, see Maxwell Cameron and Kenneth Sharpe, above n 87, at 101.

${ }^{154}$ David Landau, above n 61, at 947-948.

155 Maria Pilar Garcia-Guadilla, "Civil Society: Institutionalisation, Fragmentation, Autonomy" in Venezuelan Politics in the Chávez Era: Class, Polarisation \& Conflict, Steve Ellner and Daniel Hellinger (eds) (Lynne Reiner Publishers, Boulder, 2003), at 179, 186.

${ }^{156}$ David Landau, above n 61, at 943.

${ }^{157}$ At 942. 
highly unlikely that this kind of body would agree to a non-proportional electoral system for the convocation of an assembly, as this would mean that one party could dominate the assembly, whereas an assembly elected using a proportional system is likely to be representative to a degree, and is unlikely to be completely dominated by one party. Furthermore, Chávez would have been constrained by the interim constitution, which may have prevented the self-aggrandisement that appeared in the constitution. The constitution which emerged from the process had elements of self-interest that may not have emerged from a more representative assembly which was limited by an interim constitution. For example, the previous constitution allowed one term for the President, whereas the new constitution extended this to two, as well as extending the length of each term. ${ }^{158}$ Overall, the new constitution "enabled the executive to massively expand its powers," and to reduce the separation of powers. ${ }^{159}$

\section{Russia (1993)}

Boris Yeltsin was the first elected president in post-communist Russia. By the time he was elected, Russia's constitution had been amended thoroughly since the communist era, and a system including an elected president, and a constitutional court had been established. ${ }^{160}$ The Constitutional Court upheld the separation of powers by striking down ultra vires uses of power by both Parliament and the President. ${ }^{161}$

However, Yeltsin and his supporters were opposed to the constitutional limits on presidential power, so they set about undermining these limits by promoting the supremacy of the President and critiquing the current allocation of power within the constitution. One of Yeltsin's aides described the justification for the 'superior power' of the President as being that the President's power emanates from popular sovereignty. According to William Partlett, the aide effectively claimed that "the Russian Presidency's power flowed directly from its embodiment of constituent power." "162 Yeltsin also attempted to de-legitimise the main institutions which bridled the President's power - Parliament and the Constitutional Court by claiming that they were relics of the communist era and did not represent the people's power.

Yeltsin was frustrated with the restraints on Presidential power in the existing constitution. After a messy affair of political toing and froing, ${ }^{163}$ he held a referendum in which one of the questions was "Do you have confidence in your President"? After receiving 58 per-cent of the vote in his favour on this question, he took it as a mandate for abolishing the existing constitution and expanding the President's powers. The justification for this was

\footnotetext{
${ }^{158}$ Constitution of the Bolivarian Republic of Venezuela, Article 230.

${ }^{159}$ Maxwell Cameron and Kenneth Sharpe, above n 87, at 112.

${ }^{160}$ William Partlett, above n 11, at 210.

${ }^{161}$ At 212 .

162 At 214 .

${ }^{163}$ For more on the interplay between the President, and the other state powers, in the making of the Russian Constitution, regarding the proposed powers of the President within the Constitution, see Rett R, Ludwikowski, "Constitution Making in the Countries of Former Soviet Dominance: Current Development", (1993) 232 GA. J. Int'1. \& Comp. L 155, at 169-173.
} 
that the people had exercised their constituent power by expressing their confidence in the President, and he was now the embodiment of their constituent power. ${ }^{164}$

He then appointed, rather than elected, a constituent assembly, which was controlled by his closest aides. In line with the constituent power theory, he declared that the Assembly was an extra legal body which was above the constituted powers (i.e. Parliament and the Judiciary). ${ }^{165}$ Importantly, Yeltsin enjoyed political and economic support from the U.S. For example, an article in the New York Times stated that Yeltsin had "rough-and-ready democratic legitimacy for his decrees."166 Another New York Times article in support of Yeltsin stated that "a popularly elected president might have more authority than a legal but dysfunctional assembly." 167 Not only was there support in U.S media, the U.S Government provided Yeltsin with financial support. The Senate majority leader George Mitchell stated that they supported him because his views were "consistent with the views of the overwhelming majority of the Russian people."168 Indeed, Yeltsin did enjoy some popular support for his measures, but it was hardly overwhelming; a 1993 survey found that 50 percent of Russians believed Yeltsin's reliance on the military to "control the situation" was warranted. ${ }^{169}$

President Yeltsin proceeded to disband the elected Parliament and the Constitutional Court, and drafted a constitution conferring vast powers on the President, which was duly ratified by the people. ${ }^{170}$ An example of the President's power was that he was placed above the traditional tripartite separation of powers within the new constitution. ${ }^{171}$ If the lower house of Parliament (the Duma) rejected the President's choice of Prime Minister then the constitution provided that the president must dissolve the Duma and appoint a Prime Minister. ${ }^{172}$ The constitution took away some of the democratic nature of the previous constitution because it provided that the Federation Council (the senate) would be 'formed' rather than 'elected' ${ }^{173}$ This was done so Yeltsin could stack the council in his favour. To complete his control over the state, the constitution gave the President unchecked power to appoint all the members of the Supreme Court and the Constitutional Court. ${ }^{174}$ The public stance that was expressed by one of his aides admitted that the constitution was un-democratic by referring to it as "enlightened authoritarianism.".

\footnotetext{
${ }^{164}$ At 218 .

${ }^{165}$ At 219.

${ }^{166}$ Editorial, Russia: A Democrat's Coup, N.Y Times, Sept 22, 1993, at A26.

${ }^{167}$ Serge Schmemann, In Russia, Legitimacy Remains an Elusive Goal, N.Y. TIMES, Sept. 26, 1993, at E1.

168 Thomas L. Friedman, Showdown in Moscow; U.S. to Speed Money to Bolster Yeltsin, N.Y. TIMES, Sept. 23, 1993, at A13.

${ }^{169}$ Survey conducted by LABADA-TSENTR, Rossiiane o sobytiiakh 3-4 oktiabria 1993 goda [Russians on the events of October 3-4, 1993] (Oct. 3, 2005), <www.levada.ru/press/2005100301.html>

${ }^{170}$ William Partlett, above n 11, at 225. However, many Western commentators focussed on the large amount of individual rights contained in the new constitution, William Partlett, above n 11, at 223-224.

${ }^{171}$ William Partlett, above n 11, at 224.

172 Constitution of the Russian Federation 1993, Article 111 (4).

173 William Partlett, above n 11, at 225; see also Paul Chaisty, Legislative Politics and Executive Power in Russia, (Palgrave MacMillian, Hampshire, 2006), at 104.

${ }^{174}$ William Partlett, above n 11, at 225.

${ }^{175}$ Eugene Huskey, Presidential Power in Russia, (M.E Sharpe, New York, 1999), at 32.
} 
According to William Partlett, Boris Yeltsin used the constituent power theory to create a "plebiscitary dictatorship in the garb of liberal constitutionalism." 176 Yeltsin appeared to take advantage of the constituent power theory in order to validate any action he saw fit. As with the Bolivian and Venezuelan examples, the round table model may have removed his opportunity to control the process unilaterally. For example it is unlikely that a negotiated interim constitution would agree to Yeltsin simply appointing a constituent assembly, and to disbanding the organs of government.

\section{South Africa (1996)}

The South African constitution making process that culminated in the adoption of a constitution in 1996 is viewed by many as a successful example of popular participation. ${ }^{177}$ And, the text itself is "widely regarded as a model constitutional text." 178 Although South Africa had three previous constitutions, this was the first one that was adopted through a democratically constituted body representing all South Africans. ${ }^{179}$ As well as the abolition of apartheid, the 1996 constitution marked a shift from parliamentary sovereignty to constitutional supremacy, with a super-majority needed within parliament to change constitutional provisions, and a role for the judiciary in upholding the constitution. ${ }^{180}$

The process occurred in the context of the democratic transition marking the end of apartheid. ${ }^{181}$ It involved two major stages. The first stage, from $1990-1994$, involved the major parties negotiating an interim constitution. The major parties that were involved were the National Party (the apartheid government party), the African National Congress (ANC), and the Inkatha Freedom Party (IFP). The second stage was the election of a Constituent Assembly to make the constitution. The Assembly was constrained by the principles agreed upon in the negotiating stage and contained in the interim constitution. ${ }^{182}$

There was no formal popular participation in the negotiation of the interim constitution. ${ }^{183}$ The first multi-party talks were held at the Convention for a Democratic South Africa in late 1991. The multi-party forum was able to agree on many fundamental issues, including a multi-party democracy in a united South Africa, with an entrenched and justiciable bill of rights. The convention appeared to be a promising start, but then it became clear that the National Party was seeking to control the process, and maintain their power through constitutional gerrymandering. ${ }^{184}$ The Government insisted on federalism as a pre-

\footnotetext{
${ }^{176}$ William Partlett, above n 11, at 210.

${ }^{177}$ Heinz Klug, South Africa's Experience in Constitution-Building (Univ. of Wisconsin Legal Studies Research Paper Series Paper No. 1157, April 12, 2011), at 3; D.M Davis, "Constitutional Borrowing: the South Africa Experience" (2003) 12 Int. J. Const. L 181, at 181; Heinz Klug, "Participation in the Design: ConstitutionMaking in South Africa" 19963 Rev. Const. Studies 18.

${ }^{178}$ Vivien Hart, above n 10, at 7.

${ }^{179}$ Heinz Klug, South Africa's Experience in Constitution-Building above n 177, at 2; for more on the South African process see Kirsti Samuels and Vanessa Hawkens Wyeth, State Building and Constitutional Design after Conflict (International Peace Academy, 2006); and D.M Davis, above n 173.

${ }^{180}$ Heinz Klug, South Africa's Experience in Constitution-Building above n 177, at 5.

${ }^{181}$ At 6.

182 At 7 .

${ }^{183}$ Dann, Philipp et al, above n 4, at 5.

${ }^{184}$ Heinz Klug, South Africa's Experience in Constitution-Building above n 177, at 9.
} 
condition to the democratically elected constituent assembly, because they wanted to have greater regional autonomy, and maintain Bantustans. It was this condition, amongst others, that led to the breakdown of these negotiations. ${ }^{185}$

In response to this, the ANC rallied with its supporting Labour and Communist movements, and began mass demonstrations, agitating for the election of a constituent assembly. In turn, these demonstrations were met with violence from opposition forces, which culminated in the Boipatong massacre - in a township that supported the ANC - where around 40 people were killed. ${ }^{186}$ The ANC then formally announced that they were suspending multi-party negotiations, and made various demands of the Government, including that they release the (approximately) 300 political prisoners they were holding in contravention of earlier agreements, and that they ban their supporting parties (the IFP) from carrying lethal weapons. ${ }^{187}$

Following this, it appeared that the National Party might be willing to compromise in order to draw the ANC back into negotiations, as they made concessions like accepting international observers, and expanding peace accord structures designed to reduce conflict in specific communities. ${ }^{188}$ However, while they agreed in word to the end of apartheid, they would not disband the systems in place in right winged white communities and Bantustans that implemented apartheid. ${ }^{189}$

Some members of the ANC and the Communist party had sought inspiration from Eastern Europe where they had recently witnessed people's revolutions in which socialist regimes had been transformed. The non-violent revolution in Germany, where the Berlin wall was felled as a result of mass mobilisation, was particularly inspirational. ${ }^{190}$ They called for an interim government to take over from the apartheid regime, and used mass mobilisation to pressure the government to this end. They proposed an Act that set up an interim government and the election of a constituent assembly to make a constitution. There was a lot of popular support for this Act, with over four million workers striking for two days in support of the proposed Act. ${ }^{191}$

However, after this promising start, things took a turn for the worse when the ANC turned their attention to the Bantustans. Twenty thousand ANC members marched on the Ciseki Bantustan, and were fired at by security forces, with 28 ANC members killed and over 200 injured. A massacre followed at Bishop which ended that round of negotiations. ${ }^{192}$ At

\footnotetext{
185 At 9.

${ }^{186}$ At 10 .

${ }^{187}$ At 10 .

${ }^{188}$ At 11.

${ }^{189}$ At 11.

${ }^{190}$ At 11 .

${ }^{191}$ At 12.

${ }^{192}$ At 12 .
} 
this point the ANC realised that they could not replicate the successful non-violent revolution in Germany. ${ }^{193}$

Notwithstanding the brutal violence, negotiations resumed after a short while with the Record of Understanding reached between the parties. Compromise was needed to break the deadlock; the National Party agreed to the election of a constituent assembly and the ANC conceded to having an interim Government of National Unity (meaning that all parties were represented, including the National Party). ${ }^{194}$

The negotiated interim constitution entrenched the Government of National Unity for five years, which gave the National Party the legal continuity they desired. But not long after negotiations resumed, the leader of the Communist Party (and an ANC member) Chris Hani was assassinated by a white man associated with right wing politics. Despite this, negotiations continued, and the interim constitution was finalised by the end of 1993 . The first democratic elections were to be held the following year.

Key features of the interim constitution were that the final constitution was to be made within two years of the first sitting of the Constituent Assembly. A super majority of two thirds of the Assembly was required to pass the constitution into law, and the Constitutional Court was to certify that the constitution complied with the principles laid down in the interim constitution. On one occasion, the Constitutional Court exercised their power by striking down a proposed provision to implement the death penalty, which was supported by the majority of South Africans, ${ }^{195}$ because it violated the principles contained in the interim constitution. ${ }^{196}$ The threshold was later lowered to 60 per-cent, but the constitution ended up passing with an 87 per-cent majority. Heinz Klug claims that the high threshold for the constitution's promulgation helped to ensure a spirit of compromise. ${ }^{197}$ To this I would add that the internal diversity of the Assembly also ensured a spirit of compromise.

Provision for the election of a constituent assembly was provided for in Chapter Five of the interim constitution. The Assembly was comprised of the two houses of Parliament; the National Assembly and the Senate, so is more aptly described as a 'constituent legislature. ${ }^{198}$ It was broadly representative, consisting of 490 members from seven political parties. The Assembly set up a 44 person constitutional committee to provide administrative support and to implement the public participation initiatives. ${ }^{199}$ In addition, six theme committees consisting of policy and legal experts were set up to collect information, views, opinions, ideas, and submissions on the content of the constitution. ${ }^{200}$ The theme committees held seminars on specific aspects of the constitution and invited participation from interest

${ }^{193}$ Ronnie Kasrils, Armed and Dangerous: My Undercover Struggle Against Apartheid, (Heinemann Educational, Oxford, 1993), at 301.

${ }^{194}$ At 12.

195 Michelle Brandt et al, above n 10, at 116.

${ }^{196} S v$ Makwanyane and Another, CCT 3/94 [1995] ZACC 3.

${ }^{197}$ Heinz Klug, South Africa's Experience in Constitution-Building above n 177, at 13.

198 At 14.

199 At 14 .

${ }^{200}$ At 14 . 
groups, academics, and non-governmental organisations, as well as other members of the Assembly. There was even a technical refinement team to ensure that the text of the constitution was consistent and easily understood. ${ }^{201}$ An independent panel of seven constitutional experts was engaged to provide advice and to help resolve disputes in the event of a deadlock if the Assembly was unable to attain the required two thirds majority within the two year time frame. ${ }^{202}$

During the drafting stage, the Assembly implemented a broad public participation and consultation programme. The process adhered to the three principles of accessibility, inclusivity, and transparency. ${ }^{203}$ It began with a comprehensive education campaign, informing the public about constitutional issues in general, fundamental rights, and their right to participate. Throughout the drafting stage a variety of media were used to keep the public informed, and allow them to participate; including bi-weekly Assembly newspapers, billboards, radio and television, the internet, and a telephone hotline. Citizens were actively encouraged to make submissions to the committee, and workshops were held all over the country. ${ }^{204} \mathrm{~A}$ central element in the programme of participation was public meetings where members of the Assembly presented their work and the public could express their views in response to this. Everything that was said at the meetings was recorded and transcribed. ${ }^{205}$ As well as general meetings, specific meetings were held on topics like the bill of rights and the judiciary. ${ }^{206}$ An Assembly radio programme was broadcast in eight languages and reached around ten million people per week (approximately a quarter of the population). ${ }^{207}$ The overall campaign of public engagement reached approximately 73 per-cent of South Africans. $^{208}$

The Assembly received 13,443 submissions, ${ }^{209}$ and approximately two million people signed various petitions. ${ }^{210}$ The submissions were processed by the secretariat of the Assembly and edited into a more accessible format by the teams working on various aspects of the constitution. Special consideration was given to submissions from groups with specialised knowledge on certain issues. ${ }^{211}$

The third stage followed publication of the draft text. Public submissions were again received and attached to the various articles for consideration by the Assembly in the final negotiation process. Some people criticised this phase as the final negotiation was done

\footnotetext{
201 At 14 .

202 At 15.

${ }^{203}$ Philipp Dann et al, above n 4, at 5 .

204 At 5.

205 At 5.

${ }^{206}$ At 5 .

207 At 6.

${ }^{208}$ Vivien Hart, above n 10, at 7.

${ }^{209}$ Catherine Barnes and Eldred De Clerk, South Africa's Multi Party Constitutional Negotiation Process, (Accord 13, 2002).

${ }^{210}$ Philipp Dann et al, above n 4, at 6 .

211 At 6. 
behind closed doors, ${ }^{212}$ and it is not clear how much consideration the submissions were given.

But nevertheless, the process was seen as a success by many. Phillip Dann considered that the comprehensive civic education process and the direct engagement with the citizens were crucial to the successful integration of public participation into the process. A survey indicated that knowledge of the constitution was fairly high, and that many people felt a sense of ownership of the constitution due to the highly participatory nature of the constitution making process. ${ }^{213}$ On May 8 1996, 87 per-cent of the Assembly voted in favour of the constitution, and it became law. ${ }^{214}$

While the South African process has been widely lauded, it has also received criticism. Firstly, it has been said that the participation was largely limited to the middle class and the "urban intelligentsia", ${ }^{215}$ and that the large rural population was either bypassed or were disinterested in the process. Others have questioned the wisdom in receiving so many submissions, and doubt that a constitutional draftsman could actually read and review them all, let alone take them all into consideration. ${ }^{216}$ Some have even said that the whole process was an "elaborate hoax," designed to mask the fact that the final constitution would be negotiated behind closed doors by elites, and would not be submitted for public approval. ${ }^{217}$ Indeed, many African examples are conspicuous for not putting approval of the text to a referendum, but for having broad programmes of participation in the drafting stage. ${ }^{218}$

There is no doubt that because the international spotlight was on South Africa due to the international denunciation of the apartheid regime they would have wanted to be seen to be doing the right thing by the international community, in terms of implementing a comprehensive public participation programme. But this does not necessarily mean that the whole public participation process was a sham. Obviously there would be difficulties in meaningfully processing the plethora of public submissions, but this does not mean the process was a waste of time and energy. Even if each submission did not have a substantive effect on the final constitution there is still an inherent value in giving people a voice. Also, the educational value of the process cannot be overlooked.

In my view, the most important element in the South African process was the use of the round table model. This is a critical element that was notably absent in the previously discussed constitution making episodes. The main benefit to be gained from the negotiation phase is the setting of clear parameters for the constitution making process, and the

\footnotetext{
212 At 6.

${ }^{213}$ Hassem Ebrahim, The Soul of a Nation: Constitution Making in South Africa, (Oxford University Press, Cape Town, 1998), at 24.

${ }^{214}$ Heinz Klug, South Africa's Experience in Constitution-Building above n 177, at 16.

${ }^{215}$ I. G, Shivji, "Three Generations of Constitutions and Constitution-Making in Africa: An Overview and Assessment in Social and Economic Context," in M.S Rosen ed. Constitutionalism in Transition: Africa and Eastern Europe, (Helsinki Foundation for Human Rights, 2003), at 86.

216 Thomas Franck, above n 10, at 10.

${ }^{217}$ Christina Murray, “A Constitutional Beginning: Making South Africa's Final Constitution”, (2000-2001) 23

UALR Law. Rev. 809, at 821-822.

${ }^{218}$ Thomas Franck, above n 10, at 10-11. 
prevention of an unlimited constitution making body that is tailor-made for one group to impose a constitution. In the South African episode all the actors involved were aware of their role and their powers. In particular, there was no debate over whether or not the Assembly could exercise unlimited constitution making power, because this question had been resolved during negotiation, with the result that principles that would bind the Assembly were agreed upon, and the Constitutional Court was charged with upholding them. And, the Court exercised this power by striking down a proposed provision in the constitution to allow the death penalty. ${ }^{219}$ The alternative to the round table model is a 'winner takes all' approach, where the victor in a national election can ascribe constituent power to themselves for the benefit of ramming home their own agenda unimpeded. This eventuality occurred in both Venezuela and Russia, and almost occurred in Bolivia.

\section{Implications of the Case Studies}

In my view, the round table model, with the negotiating phase prior to the election of a constituent assembly, is the most desirable method for making a constitution. The main purpose of this body is to set the ground rules for the constitution making process - via an interim constitution - before the drafting of the final constitution begins. The advantage of this is that it gives some certainty to the process in that everyone will be aware of the rules of the process before it begins. If the rules are set out in initially, then the limits placed on the assembly will be less likely to be contested. It may also reduce the likelihood of people trying to skew the rules of the process in their favour, either before the process begins, or once it is already underway. In my view, the Bolivian, Venezuelan, and Russian processes all suffered due to a lack of preconceived rules.

In Bolivia, Morales claimed that the Assembly was exercising constituent power and was above the constituted powers of the state, whereas the opposition claimed that there were external limits on the Assembly. Eventually limits were successfully placed on the Assembly but the whole process could have been a lot smoother if the rules were agreed beforehand.

As explained earlier, Chávez used a non-proportional voting system to completely dominate the Assembly. Along with numerical dominance in the Assembly, it was not clear what the rules for the process were. Chávez was able to manipulate the process to his advantage, and cement control over the state institutions by relying on the constituent power theory.

If, as I argue they should be, the rules for the process were laid out beforehand by a representative body, it is unlikely that Chávez could have proceeded as he did. The following manoeuvres would simply not be accepted by, and agreed upon, by a broadly representative body:

(i) setting the rules for election of the assembly to ensure his coalition completely dominated the Assembly; ${ }^{220}$ and

\footnotetext{
${ }^{219}$ S v Makwanyane and Another, CCT 3/94 [1995] ZACC 3.

${ }^{220}$ David Landau, above n 61, at 941.
} 
(ii) declaring a state of emergency once the Assembly was convened and using this as authorisation to reorganise state powers. This power was used to remove any opposition from the judiciary and to threaten to dismantle the Supreme Court if they attempted to interfere with the assembly's work; ${ }^{221}$ and

(iii) dissolving the Congress and replacing it with a National Legislative Assembly appointed by the Constituent Assembly; ${ }^{222}$ and

(iv) granting of legislative powers to the Constituent Assembly. ${ }^{223}$

This also shows the danger of carrying out a constitution making episode in the midst of wide spread support for constitutional change. In my view, it is important that the momentum for constitutional change comes from 'below,' but when it occurs, it should trigger a negotiation phase to set the ground rules constitution making process. It should not trigger the drafting of the final constitution. When the process occurs concurrently with the 'constitutional moment', without any preconceived ground rules, it can be too easy for a dominant individual or group to use the constituent power theory to their own advantage.

There are parallels between the process in Venezuela and Russia. In Russia, as with Venezuela, there were no rules to govern the process and it was not clear what powers the Assembly or the pre-existing governmental institutions would have. Within this void, Yeltsin implemented policies and manoeuvres as and when he saw he fit, in order to solidify his power and to craft a constitution to his liking. As described in Part V, he declared himself to be the embodiment of people's power by virtue of a referendum where the majority (although not a large majority) declared their confidence in him as President. Quite apart from the fact that there is no necessary correlation between the people declaring their confidence in a president and that president being a personification of constituent power, the procedures he implemented following this were decidedly lacking in democratic pedigree. This was seen most directly in the appointment of, rather than election of, a Constituent Assembly, but also in the dismantling of the democratically elected Parliament. The process bears a striking resemblance to the Venezuelan process. Chávez's methods were ostensibly more democratic as the Assembly was elected, but because it was done so non-proportionally Chávez was also able to ensure that there would be no opposition to his constitution making agenda.

There was no real mandate for either Chávez or Yeltsin to proceed as they did. In neither case were they following rules agreed upon by broad consensus. Nor were they elected by the people, whose constituent power they claimed to be exercising, with the mandate to dismantle, and then unilaterally re-populate state organs to ensure their complicity in their constitution making exercises.

In contrast with Bolivia, Venezuela, and Russia, the process of constitution making in South Africa was preconceived before the actual drafting began. The Constituent Assembly did not have unlimited constitution making power as they were bound by the principles laid

${ }^{221}$ At 946.
${ }^{222}$ At 948.
${ }^{223}$ At 948. 
down in the interim constitution. The newly created Constitutional Court was the guardian of these principles, and used their power to strike down a proposed provision to implement the death penalty, even though the proposal had received substantial popular support. ${ }^{224}$

Another danger with convoking the constituent assembly as the constitutional moment is at its peak, is that high levels of popular participation may have an inhibitory effect on the Assembly. It may limit the options for the drafters, in terms of the substance of the constitution, if there is a passionate and polarised public, as there may be less scope to negotiate between the elites for fear of inflaming the passions of the people by going against their wishes. This situation, which occurred in Bolivia, may limit the scope for meaningful dialogue. If there had been a round table phase, it may not have eliminated the violence, but it may not have had as disruptive an influence on the constitution making process if the violence occurred during the interim constitution making phase. In particular, the Assembly may have had more room to negotiate the text in a less anxious and charged atmosphere, and possibly could have had more scope to compromise. Instead, the threat of violence loomed large throughout.

Although there was a lot of violence during the round table phase in South Africa, this had largely been quelled by the time the Assembly was elected. This meant that during the crucial drafting stage, the Assembly was not working against the backdrop of a highly passionate and vigilant public, formed into opposing groups with an 'us and against them' mentality. As a result, they may have had more options available to them in terms of the substance of the constitutional text.

As discussed earlier, under my conception of constitution making, popular participation is of secondary importance to the negotiation phase in the round table model, as it is this phase which will determine the method for convening the formalised constitution making body, which, in the end, may have a greater influence on the text of the constitution than the public will. Although the South African process is widely praised as a highly participatory process it is unclear how much influence popular participation had on the text of the constitution. ${ }^{225}$ The sheer volume of public submissions meant that it was impossible to incorporate all the ideas into the constitution. However, this will always be the case in any modern constitution making episode. In this respect, the round table model outlined earlier may be a more important aspect in the process than high levels of popular participation, as the interim constitution making phase is likely to lead to a representative constitution making body and may prevent one group dominating the process. Popular participation can accomplish neither of these objectives. And, moreover, irrespective of whether or not there are high levels of popular participation, it will usually be elites who are the formal constitution makers, at least in terms of drafting the constitution. Bearing this in mind, it is most important that there is a representative group of elites who form the constitution making body as they are the group who will have the most influence on the actual substance of the constitution. There are many historical examples of stable, democratic constitutions made

\footnotetext{
${ }^{224} S v$ Makwanyane and Another CCT/3 94 [1995] ZACC 3.

${ }^{225}$ Joel I. Colón-Ríos, above n 5.
} 
without any real popular participation. These include the Canadian, ${ }^{226} \mathrm{US}^{227}$ German, ${ }^{228}$ and Japanese constitutions. $^{229}$

This is not to say that popular participation serves no purpose. In particular, participation in the form of public submissions to the constitution making body, constitutional workshops, and the comprehensive education programme, as it occurred in South Africa may be beneficial. Firstly, it lends democratic legitimacy to the constitution, because it gives some effect to the notion of government by the people, which is at the core of democracy. Secondly, it empowers people by giving them a voice. Even though the power of the public to influence the text may be limited, ${ }^{230}$ and each voice will not have an effect on the content of the constitution, there is still some intangible benefit in simply giving people the opportunity to express themselves. Thirdly, and this point is connected to the last point, a highly participatory process may give people a sense of ownership of the constitution. ${ }^{231}$ And lastly, it may increase people's knowledge of the constitution and their rights. ${ }^{232}$

In my view, popular participation was not the major issue in the Bolivian and Venezuelan episodes that Landau addressed; it was the absence of a round table phase. In the Bolivian case, this would have removed the confusion over the ratification of the constitution, and clarified that the Constituent Assembly would not exercise constituent power. The violence that occurred may have been unavoidable, but it may have been less disruptive to the constitution making process if it occurred during the round table phase, rather than the drafting stage. In Venezuela, the round table phase could have restrained Chávez's unilateral exercise of power, by the implementation of a proportional voting system.

\section{Conclusion}

In this paper I presented the round table model as a form of constitution making that addresses both the theoretical and practical issues with the constituent power theory. With reference to the Bolivian, Venezuelan, Russian, and South African episodes, I attempted to show that the primary danger of the practical manifestation of the constituent power theory in a constituent assembly - the unilateral imposition of a constitution by a dominant group or individual - may be prevented by the implementation of the round table model. With reference to the Bolivian experience, I argued that another benefit of the round table model is providing clarity for the powers and roles of all the actors within the process. Further, I argued that there are risks involved in convening an assembly in the midst of a 'constitutional

\footnotetext{
${ }^{226}$ For discussion of the Canadian constitution-making process see Peter H. Russell, Constitutional Odyssey: Can Canadians Become a Sovereign People? (University of Toronto Press, Toronto, 1993).

${ }^{227}$ For discussion of the US constitution making process see Max M. Edling, A Revolution in Favour of Government: Origins of the U.S Constitution and the Making of the U.S State, (Oxford University Press, New York, 2003).

${ }^{228}$ For discussion of the German Constitution making process see Ford, J. Golay, The Founding of the Federal Republic of Germany, (University of Chicago Press, Chicago, 1958).

${ }^{229}$ For discussion of the Japanese constitution making process see K. Inoue, MacArthur's Japanese Constitution: a Linguistic and Cultural Study of its Making, (Chicago University Press, Chicago, 1991).

${ }^{230}$ Angela Banks "Expanding Participation in Constitution-Making: Challenges and Opportunities" (2008) 49

Wm \& Mary LR 1043, at 1056.

${ }^{231}$ Philipp Dann, above $\mathrm{n}$, at 2.

232 At 6. 
moment,' and in this respect, the round table model is preferable, as the drafting of the final constitution will be preceded by the interim constitution making phase. Finally, while promoting the importance of popular participation, I placed paramount importance on the need for the round table model, because, in my view, the elites will have more influence on the constitutional text than the people. Thus, I place more emphasis on the regulation of the elites within the process than I do on ensuring a highly participatory process.

Before addressing the round table model, it was necessary to outline the dominant theory of constitution making; that the people's constituent power must be embodied in a constituent assembly that is imbued with unlimited constitution making power, and that the process must be highly participatory, to ensure the democratic legitimacy of the constitution through its authorship by the people. Following this, I reviewed some of the critiques of the constituent power theory, and attempted to show that the theory itself is not impenetrable, as the assumptions upon which the theory rests are questionable. Building on Vinx's work, I argued that the idea that the people who comprise a nation must share a common primary identity in order for the constitution to be legitimate is inapplicable in a modern nation. I then outlined the argument that the primordial nature of the people, as a collective political body, existing prior to and independent of a constitution, is illogical and contrary to historical fact, as it is usually a group of elites who create a constitution which is then given to the people. 


\section{Bibliography}

A Articles

Arato, Andrew, "Conventions, Constituent Assemblies, and Round Tables: Models, Principles and Elements of Democratic Constitution-Making” (2012) 1 Global Constitutionalism 173.

Arato, Andrew "Post-Sovereign Constitution-Making and Its Pathology in Iraq" (2006-2007) 51 NYLSLR 535.

Arato, Andrew, "Redeeming the Still Redeemable: Post Sovereign Constitution Making" (2009) 22 Int J Polit Cult Soc 427.

Arjomand, S.A, "Constitutions and the Struggle for Political Order: A Study in the Modernisation of Political Traditions" 199239 XXXIII Arch. Europe. Sociol 73.

Banks, Angela, "Expanding Participation in Constitution-Making: Challenges and Opportunities" (2008) 49 Wm \& Mary LR 1043

Barr, Robert R, "Bolivia: Another Uncompleted Revolution," (2005) 47 Latin American Politics and Society 69.

Colón-Ríos, Joel I. "Notes on Democracy and Constitution-Making” (2013) 3 VUWLRP 21.

Dann, Philipp et al, Lessons Learned from Constitution-Making: Processes with Broad Based Public Participation (Democracy Reporting International, Briefing Paper No.20, November 2011).

Davis, D.M "Constitutional Borrowing: the South Africa Experience" (2003) 12 Int. J. Const. L 181.

Duverger, Maurice "Legitimite des Gouvernements de fait" (1948) Revue du Droit Publique.

Elkins, Zackary et al, "The Citizen as Founder: Public Participation in Constitutional Approval” (2011) 81 TLR 101.

Elkins, Zachary et al, "Baghdad, Tokyo, Kabul...Constitution Making in Occupied States" (2008) 49 Wm. \& Mary LR. 1139.

Ginsburgh, Tom et al, "Does the Process of Constitution-Making Matter?" (2009) 47 Annu. Rev. Law Soc. Sci. 5.1.

Kalyvas, Andreas, "Popular Sovereignty, Democracy, and the Constituent Power" (2005) 12 Constellations 223.

Kis, Janos, "Popular Sovereignty: The Classical Doctrine and its Criticism" 20061 Rev. Pol. Sci. 5. 
Klug, Heinz, "Participation in the Design: Constitution Making in South Africa," (1996) 31 Rev. Const. Studies, 19.

Klug, Heinz, "South Africa's Experience in Constitution-Building" Univ. of Wisconsin Legal Studies Research Paper Series Paper No. 1157 (April 12, 2011).

Landau, David, “Constitution-Making Gone Wrong” (2013) 645 ALR 923.

Law, David S. and Versteeg, Mila, "Sham Constitutions," (2013) 1014 CLR 863.

Lehoucq, Fabrice, “Bolivia’s Constitutional Breakdown” (2008) 19 J. Democracy 110.

Ludwikowski, Rett R, "Constitution Making in the Countries of Former Soviet Dominance: Current Development”, (1993) 232 GA. J. Int'l. \& Comp. L 155.

Murray, Christina, “A Constitutional Beginning: Making South Africa's Final Constitution”, (2000-2001) 23 UALR Law. Rev. 809.

Partlett, William “The Dangers of Popular Constitution-Making” (2012) 381 Brook. J. Int'L L. 193.

Van Cott, Donna Lee "Andean Indigenous Movements and Constitutional Transformation: Venezuela in Comparative Perspective” (2003) 301 Latin American Perspectives 49.

Vinx, Lars, “The Incoherence of Strong Popular Sovereignty” (2013) 11 I CON 101.

B Books

Cameron, Maxwell and Sharpe, Kenneth "Andean Left Turns: Constituent Power and Constitution-Making" in Maxwell Cameron and Eric Hershberg (eds) Latin American Left Turns: Politics, Policies, and Trajectories of Change“(Lynne Rienner Publishers, Boulder, 2010).

Chaisty, Paul, Legislative Politics and Executive Power in Russia, (Palgrave Macmillan, Hampshire, 2006).

de Smith, S.A The New Common-Wealth and Its Constitutions, (London, Stevens and Sons, 1964).

Dyzenhaus, David, Legality and Legitimacy: Carl Schmitt, Hans Keller and Hermann Heller in Weimar, (Oxford, 1999).

Ebrahim, Hassem, The Soul of a Nation: Constitution Making in South Africa, (Oxford University Press, Cape Town, 1998).

Edling, Max M, A Revolution in Favour of Government: Origins of the U.S Constitution and the Making of the U.S State, (Oxford University Press, New York, 2003). 
Ellner, Steve, Rethinking Venezuelan Politics: Class, Conflict, and the Chavez Phenomenon, (Lynne Rienner Publishers, Boulder, 2008).

Elster, Jon, "Legislatures as Constituent Assemblies" In Richard Brauman and Tsvi Kahana (ed) The Least Examined Branch: The Role of Legislatures in the Constitutional State, (Cambridge University Press, Cambridge, 2006).

Elster, Jon, "Ways of Constitution-Making" In Axel Hadenus (ed) Democracy's Victory and Crisis (Cambridge University Press, Cambridge, 1997).

Franck, Thomas and Thiruvengadam, Arun, "Norms of International Law Relating to the Constitution-Making Process", in Framing the State in Times of Transition: Case Studies in Constitution-Making (Laurel E Miller, 2010).

Gamarra, Eduardo A, "Bolivia: Evo Morales and Democracy," in Constructing Democratic Governance in Latin America, Jorge I. Dominguez and Michael Shifter eds. (The John Hopkins University Press, Maryland, 2003).

Garcia-Guadilla, Maria Pilar, "Civil Society: Institutionalisation, Fragmentation, Autonomy" in Venezuelan Politics in the Chavez Era: Class, Polarisation \& Conflict, Steve Ellner and Daniel Hellinger eds (Lynne Reiner Publishers, Boulder, 2003).

Golay, Ford, J, The Founding of the Federal Republic of Germany, (University of Chicago Press, Chicago, 1958).

Hauriou, Maurice, Precis de Droit Constitutionnel, 2nd ed. (Paris, Sirey, 1929).

Hofmann, Hasso, Legitimacy Against Legality: The Development of Carl Schmitt's Political Philosophy, (Duncker and Humblot, Berlin, 2002).

Huskey, Eugene, Presidential Power in Russia, (M.E Sharpe, New York, 1999).

Kahn, Paul W, Political Theology: Four New Chapters on the Concept of Sovereignty, (Colombia University Press, New York, 2012).

Kalyvas, Andreas, Democracy and the Politics of the Extraordinary: Max Weber, Carl Schmitt, and Hannah Arendt, (Cambridge University Press, Cambridge, 2009).

Kasrils, Ronnie, Armed and Dangerous: My Undercover Struggle Against Apartheid, (Heinemann Educational, Oxford, 1993).

Kelsen, Hans, On the Nature and Value of Democracy, (Tubingen J.C.B Mohr, 1929), at 1418.

Locke, John The Second Treatise of Government: An Essay Concerning the True Original, Extent, and End of Civil Government, ed. Peter Laslett (Cambridge, Cambridge University Press, 1991). 
Mayorga, Rene Antonio, "Bolivia's Democracy at the Crossroads" in The Third Wave of Democratization in Latin America: Advances and Setbacks, Francis Hagopian and Scott P. Mainwaring eds (Cambridge University Press, Cambridge, 2005).

McClellan, James and Bradford, M.E eds. Jonathon Elliot's Debates in the Several State Conventions on the Adoption of the Federal Constitution as Recommended by the General Convention at Philadelphia in 1787, (Cumberland VA: J. River, 1989) vol 2432.

Paine, Thomas, Rights of Man: Being an Answer to Mr Burke's Attack on the French Revolution, in Rights of Man, Common Sense and other Political Writings (J.S Jordan, 1791).

Russell, Peter H, Constitutional Odyssey: Can Canadians Become a Sovereign People? (University of Toronto Press, Toronto, 1993).

Schmitt, Carl Constitutional Theory (Duke University Press, Durham and London, 2008).

Segura, Renata, Inclusion and the Politics of Constitution Making: Colombia and Ecuador (1991 \&1998), (New School University, 2007).

Shivji, I. G, "Three Generations of Constitutions and Constitution-Making in Africa: An Overview and Assessment in Social and Economic Context," in M.S Rosen ed. Constitutionalism in Transition: Africa and Eastern Europe, (Helsinki Foundation for Human Rights, 2003),

Sieyes, Emanuel Joseph, What is the Third Estate? S.E Finer ed. M Blondel trans. (London, Pall Mall Press, 1963).

Franck, Thomas, and Thiruvengadam, Arun, "Norms of International Law Relating to the Constitution-Making Process", in Framing the State in Times of Transition: Case Studies in Constitution-Making (Laurel E Miller, 2010).

C Papers and Reports

Barnes, Catherine, and De Clerk, Eldred, South Africa's Multi Party Constitutional Negotiation Process, (Accord 13, 2002).

Brandt, Michelle, et al, Constitution-Making and Reform: Options for the Process (Interpeace, 2011).

Hugo Chávez Frías, Documento Fundamtentales de la Republica Bolivariana de Venezuela, (Caracas, Venezuela, Ediciones de la Presidencia de la Republica, 2000).

Dann, Philipp et al, Lessons Learned from Constitution-Making: Processes with Broad Based Public Participation (Democracy Reporting International, Briefing Paper No.20, November 2011).

Elkins, Zackary and Ginsburgh, Tom, Can We Trust Legislators to Write Constitutions? (paper presented at the conference "The Gap Between Parchment and Practise: Ambivalent Effects of Constitutions in Developing Countries," American University, May 28-29, 2013). 
Ghai, Yash The Role of Constituent Assemblies in Constitution-Making (IDEA, 2006).

Hart, Vivien, Democratic Constitution-Making (U.S Int. of Peace, 12 2003).

Madison, James, “The Federalist No. 40," The Federalist Papers, ed. Clinton Rossiter (New York, Modern Library, 1938), at 257-258

Samuels, Kirsti and Hawkens Wyeth, Vanessa, State Building and Constitutional Design after Conflict (International Peace Academy, 2006).

D Cases

BVerfG, 2BvE 2/08, 30.6.2009.

Caso: Junta Directiva de la Fundacion para los Derecrios Humanos (Supreme Court of Justice, Political-Administrative Chamber), Revista Del Derecho Publico, nos 77-80, 1999.

Caso: Gerado Blyde Perez, Clarification, (Supreme Court of Justice, Political Administrative Chamber) Revista Del Derecho Publico, 77-80, 1999.

Certification of the Constitution of the Republic of South Africa, CCT 23/96 [1996] ZACC 26.

Resolucion No. 013/2008, Mar 7, 2008.

Sv Makwanyane and Another CCT 3/94 [1995] ZACC 3.

E Newspaper Materials

Editorial, Russia: A Democrat's Coup, N.Y Times, Sept 22, 1993.

Friedman, Thomas L, Showdown in Moscow; U.S. to Speed Money to Bolster Yeltsin, N.Y. TIMES, Sept. 23, 1993, at A13.

Schmemann, Serge, In Russia, Legitimacy Remains an Elusive Goal, N.Y. TIMES, Sept. 26, 1993, at E1.

\section{F Internet Materials}

Asamblea originaria genera contradicción en el Gobierno, La Prensa, July 28, 2006, $<$ constituyentesoberana.org/info/>.

El MAS planteará poderes absolutos en la Asamblea, Agencia De Noticias Fides, Aug. 17, 2006, < constituyentesoberana.org/info/>.

Presidente lamenta convocatoria a paro, EL DIARIO, Dec. 1, 2006, $<$ constituyentesoberana.org/info/>. 
Survey conducted by LABADA-TSENTR, Rossiiane o sobytiiakh 3-4 oktiabria 1993 goda

[Russians on the events of October 3-4, 1993] (Oct. 3, 2005), $<$ www.levada.ru/press/2005100301.html $>$.

\section{G Constitutions}

Constitution of the Bolivarian Republic of Venezuela.

Constitution of the Russian Federation. 